\title{
Assessing the apparent imbalance between geochemical and biochemical indicators of meso- and bathypelagic biological activity: What the @\$\#! is wrong with present calculations of carbon budgets?
}

AB Burd

DA Hansell

DK Steinberg

Virginia Institute of Marine Science

TR Anderson

J Aristegui

Follow this and additional works at: https://scholarworks.wm.edu/vimsarticles

Part of the Marine Biology Commons

\section{Recommended Citation}

Burd, AB; Hansell, DA; Steinberg, DK; Anderson, TR; and Aristegui, J, Assessing the apparent imbalance between geochemical and biochemical indicators of meso- and bathypelagic biological activity: What the @\$! is wrong with present calculations of carbon budgets? (2010). Deep-Sea Research Part li-Topical Studies In Oceanography, 57(16), 1557-1571.

10.1016/j.dsr2.2010.02.022

This Article is brought to you for free and open access by the Virginia Institute of Marine Science at W\&M ScholarWorks. It has been accepted for inclusion in VIMS Articles by an authorized administrator of W\&M ScholarWorks. For more information, please contact scholarworks@wm.edu. 


\title{
Assessing the apparent imbalance between geochemical and biochemical indicators of meso- and bathypelagic biological activity: What the @\$\#! is wrong with present calculations of carbon budgets?
}

\author{
Adrian B. Burd $^{\mathrm{a}, *}$, Dennis A. Hansell ${ }^{\mathrm{b}}$, Deborah K. Steinberg ${ }^{\mathrm{c}}$, Thomas R. Anderson ${ }^{\mathrm{d}}$, Javier Arístegui ${ }^{\mathrm{e}}$, \\ Federico Baltar ${ }^{\mathrm{e}}$, Steven R. Beaupré ${ }^{\mathrm{f}}$, Ken O. Buesseler ${ }^{\mathrm{g}}$, Frank DeHairs ${ }^{\mathrm{h}}$, George A. Jackson ${ }^{\mathrm{i}}$, \\ David C. Kadko ${ }^{b}$, Rolf Koppelmann ${ }^{\mathrm{j}}$, Richard S. Lampitt ${ }^{\mathrm{d}}$, Toshi Nagata ${ }^{\mathrm{k}}$, Thomas Reinthaler ${ }^{1}$, \\ Carol Robinson $^{\mathrm{m}}$, Bruce H. Robison ${ }^{\mathrm{n}}$, Christian Tamburini ${ }^{\mathrm{o}}$, Tsuneo Tanaka $^{\mathrm{p}}$ \\ ${ }^{a}$ Dept. of Marine Sciences, University of Georgia, Athens, GA, 30605, USA \\ ${ }^{\mathrm{b}}$ Rosenstiel School of Marine and Atmospheric Science, University of Miami, 4600 Rickenbacker Causeway, Miami, FL 33149, USA \\ ${ }^{c}$ Virginia Institute of Marine Science, P.O. Box 1346, Rt. 1208 Greate Rd., Gloucester Point, VA 23062, USA \\ d National Oceanography Centre, University of Southampton, Waterfront Campus, Southampton SO14 3ZH, UK \\ e Facultad de Ciencias del Mar, Universidad de Las Palmas de Gran Canaria, Campus Universitario de Tafira, 35017 Las Palmas de Gran Canaria, Spain \\ ${ }^{\mathrm{f}}$ University of California, Irvine, Dept. Earth System Science, 2212 Croul Hall, Irvine, CA 92697-3100, USA \\ ${ }^{g}$ Woods Hole Oceanographic Institution, MA 25, Clark 447, Woods Hole, MA 02543, USA \\ ${ }^{\mathrm{h}}$ Vrije Universiteit Brussel, Pleinlaan 2, Brussels B-1050, Belgium \\ i Dept. of Oceanography, Texas A\&M University, College Station, TX 77843, USA \\ j Institute for Hydrobiology and Fisheries Science, University of Hamburg, Grosse Elbstrasse 133, 22767, Hamburg, Germany \\ ${ }^{\mathrm{k}}$ Ocean Research Institute, The University of Tokyo, 1-15-1 Minami-dai, Nakano-ku 164-8639, Tokyo, Japan \\ ${ }^{1}$ Netherlands Institute for Sea Research, PO Box 59, Den Burg, 1790 AB, Netherlands \\ ${ }^{\mathrm{m}}$ School of Environmental Sciences, University of East Anglia, Norwich, NR4 7TJ, UK \\ ${ }^{\mathrm{n}}$ Monterey Bay Aquarium Research Institute, 7700 Sandholt Rd., Moss Landing, CA 95039, USA \\ o LMGEM UMR 6117, CNRS - Université de la Méditerranée, 63 Avenue de Luminy, Marseille 13288, Cedex 09, France \\ ${ }^{\mathrm{p}}$ Aix-Marseille University, CNRS, LOPB-UMR 6535, OSU/COM, Campus de Luminy-Case 901, 13288 Marseille CEDEX 09, France
}

\section{A R T I C L E I N F O}

Article history:

Received 7 April 2009

Accepted 16 November 2009

Available online 12 March 2010

Keywords:

Mesopelagic

Bathypelagic

Carbon budget

Metabolic activity

Carbon flux

\begin{abstract}
A B S T R A C T
Metabolic activity in the water column below the euphotic zone is ultimately fuelled by the vertical flux of organic material from the surface. Over time, the deep ocean is presumably at steady state, with sources and sinks balanced. But recently compiled global budgets and intensive local field studies suggest that estimates of metabolic activity in the dark ocean exceed the influx of organic substrates. This imbalance indicates either the existence of unaccounted sources of organic carbon or that metabolic activity in the dark ocean is being over-estimated. Budgets of organic carbon flux and metabolic activity in the dark ocean have uncertainties associated with environmental variability, measurement capabilities, conversion parameters, and processes that are not well sampled. We present these issues and quantify associated uncertainties where possible, using a Monte Carlo analysis of a published data set to determine the probability that the imbalance can be explained purely by uncertainties in measurements and conversion factors. A sensitivity analysis demonstrates that the bacterial growth efficiencies and assumed cell carbon contents have the greatest effects on the magnitude of the carbon imbalance. Two poorly quantified sources, lateral advection of particles and a population of slowly settling particles, are discussed as providing a means of closing regional carbon budgets. Finally, we make recommendations concerning future research directions to reduce important uncertainties and allow a better determination of the magnitude and causes of the unbalanced carbon budgets.
\end{abstract}

(c) 2010 Elsevier Ltd. All rights reserved.

\footnotetext{
* Corresponding author. Tel.: +17065421604; fax: +17065425888

E-mail address: adrianb@uga.edu (A.B. Burd).
}

\section{Introduction}

Primary production occurs in the relatively thin surface layer of the ocean and yet, much to the wonder of early oceanographers (Murray, 1895), it also fuels heterotrophic activity in the dark 
ocean (i.e., from the base of the euphotic zone to the sea bed). Organic material enters the dark ocean through mixing, advection, diffusion, passive sinking, and active transport (Fig. 1). Heterotrophic consumption results in a decreasing flux of this organic material with depth. For particulate organic carbon (POC), the bulk of this decrease occurs between 100 and $1000 \mathrm{~m}$ depth (Martin et al., 1987).

Simple mass balance dictates that the decrease in POC flux is balanced by heterotrophic activity, at least at steady state. However, comparisons of microbial and metazoan carbon demand with decreases in POC flux with depth suggest an imbalance between these sinks and sources. Estimates of heterotrophic activity made during intense field studies are up to 2-3 orders of magnitude greater than estimates of the carbon supplied by sinking POC (Boyd et al., 1999; Reinthaler et al., 2006; Steinberg et al., 2008; Baltar et al., 2009a). Global budgets of these sources and sinks arrive at conflicting conclusions depending on the assumptions made. For example, Del Giorgio and Duarte (2002) argued that the highest estimates of POC flux from the surface ocean could support only half the respiration occurring in mesoand bathypelagic waters. However, Arístegui et al. (2005a) were able to close a similar budget, partly by using lower microbial respiration values.

Many studies consider only passively sinking particles as the source of organic carbon. Although sinking POC is generally regarded as the largest such source, mixing and diffusion also transport dissolved and suspended particulate organic matter to the ocean interior. In the Sargasso Sea, dissolved organic carbon (DOC) supports $15-41 \%$ of the oxygen utilization between 100 and $400 \mathrm{~m}$ (Hansell and Carlson, 2001). Globally, DOC export may account for $20 \%$ of total export (Hansell, 2002; Hansell et al., submitted), with highest contributions in the upper ocean, and lowest contributions at great depth. For example, DOC accounts for $\sim 10 \%$ of the apparent oxygen utilization (AOU) in the mesopelagic (Arístegui et al., 2002) and up to $20 \%$ in the meso and bathypelagic regions of the North Atlantic (Carlson et al., 2010). Suspended, or slowly settling particulate matter is an additional substrate source and an important component of carbon budgets in the Canary Current region of the North Atlantic (Alonso-González et al., 2009), though little is known about its dynamics (Arístegui et al., 2009). Vertically migrating zooplankton and micronekton feed in surface waters and excrete at depth, potentially supporting microbial growth in the mesopelagic zone by actively transporting dissolved and particulate organic material (Longhurst et al., 1990; Banse, 1990; Al-Mutairi and Landry, 2001; Steinberg et al., 2000, 2008). Less well established are the mortality losses of seasonally migrating zooplankton in the mesopelagic (Kobari et al., 2008).

Physical dynamics and non steady-state conditions also influence the sources and sinks of organic carbon. In some regions, such as the Arabian Sea, significant inputs may be laterally transported from the ocean margins to support the carbon demand of the mesopelagic food web (Naqvi and Shailaja, 1993, Somayajulu et al., 1996). In other regions, offshore transport by upwelling filaments can exceed offshore transport by Ekman transport (Álvarez-Salgado et al., 2007).

Estimated imbalances in the carbon budget vary spatially. Bacterial carbon demand was 3-4 times greater than the loss of sinking POC in the subtropical Pacific, but a factor of 10 times greater in the subarctic Pacific (Steinberg et al., 2008), the difference being attributed to differences in community composition and abundance. Similar discrepancies have been reported between deep benthos food supply and demand (Smith and Kaufmann, 1999).

Some components of the carbon budget are not measured directly. For example, prokaryotic respiration is commonly estimated from productivity estimates using an assumed value for the bacterial growth efficiency (BGE). Assumed ranges for such parameters give budget imbalances that range from a factor of $4-10$ at a single site (Boyd et al., 1999, Steinberg et al., 2008). Further, metabolic rates (e.g., respiration) determined at non-ambient, atmospheric pressures may be biased (Tamburini et al. 2003, 2009a).

Imbalances between organic carbon sources and sinks are fundamentally problematic and raise the question: Are we missing important sources or sinks of carbon when constructing budgets for the deep ocean, or do the budget imbalances reflect problems with our measurement methodologies? The aim of this work is to quantify uncertainties in the measurements of mesoand bathypelagic carbon demand (sinks) and carbon fluxes to the deep ocean (sources). Uncertainties that are too large to allow balanced budgets must become priority research directions.

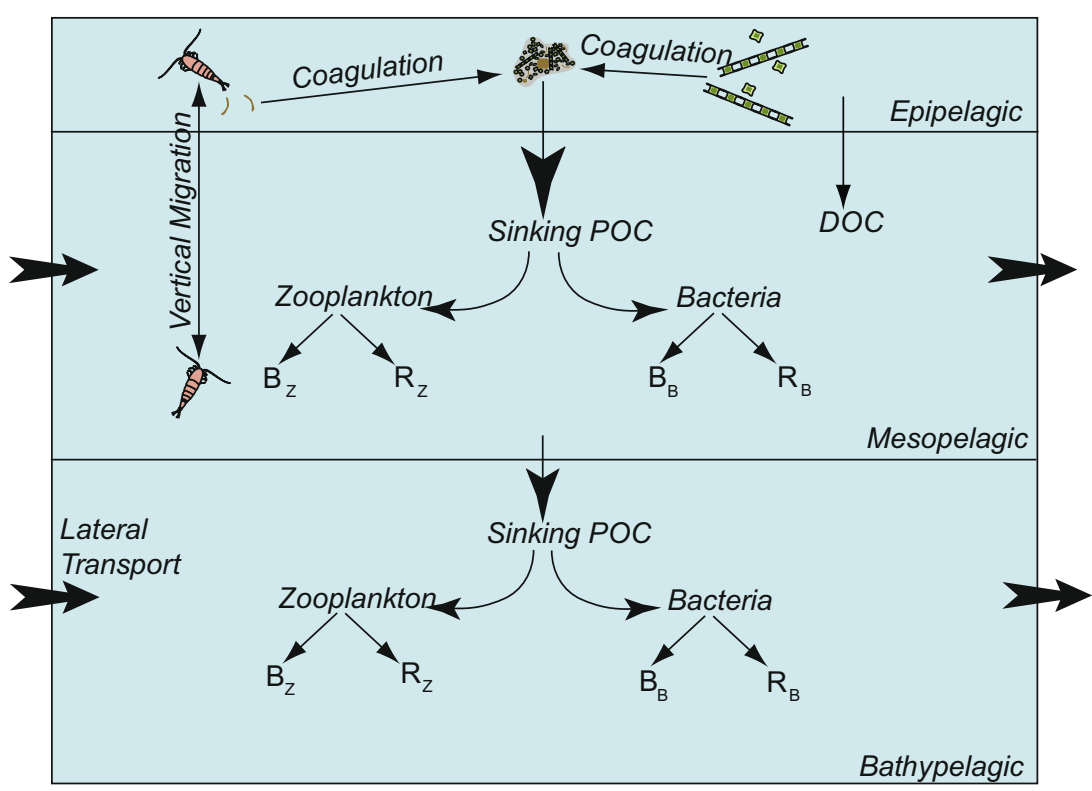

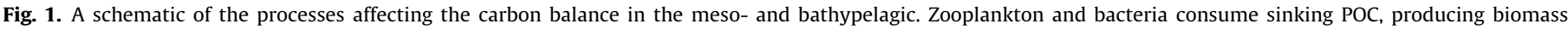

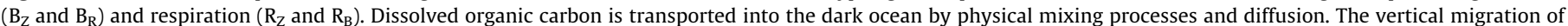
zooplankton can transport organic material from the epipelagic to the mesopelagic. 


\section{Measurement methodologies and uncertainties}

Usually, the sources of carbon included in budgets of the dark ocean are sinking POC and downward mixed DOC. The carbon sinks commonly included are microbial and mesozooplankton respiration and production. Uncertainties in these sources and sinks arise from both environmental variability and methodological inaccuracies. These uncertainties in turn determine the accuracy of local, regional and global budgets. Here, we assess and estimate the methodological uncertainties and environmental variability for the parameters used in calculating these budgets.

\subsection{Carbon sources}

\subsubsection{Particulate organic carbon vertical flux}

The downward flux of POC is generally regarded as the largest source of organic carbon to the dark ocean. Sediment traps (e.g., Honjo et al., 2008) provide the only direct measures of this flux, although they have many documented accuracy issues (e.g., Gardner, 2000; Buesseler et al., 2007), especially in the upper $1000 \mathrm{~m}$.

The performance of traps can be influenced by the hydrodynamics of the surrounding water (Butman, 1986; Gardner, 2000; Buesseler et al., 2007), the presence of zooplankton "swimmers", and particle solubilization in the trap prior to analysis (Buesseler et al., 2007). The effect of swimmers can be minimized by removing them manually or by screening after collection in a poisoned trap (e.g., Buesseler et al., 2007). Particle solubilization effects can be minimized using preservatives and by analyzing both sample particulates and filtrate to assess total fluxes into trap collection cups (Hansell and Newton, 1994; Antia, 2005). These issues can be more problematic in the upper $1000 \mathrm{~m}$, precisely where carbon imbalances are documented and vertical gradients in particle flux are largest.

Neutrally buoyant sediment traps (NBSTs) can minimize hydrodynamic effects. Particle fluxes into tubes on the same trap array vary by $20-30 \%$, but material caught in NBSTs can differ in composition from that caught in standard Particle Interceptor Traps (PITs). For example, in the deep ocean waters off Bermuda, PIT traps collected 2-3 times more swimmers, fecal pellets and ${ }^{234}$ Th than an NBST (Buesseler et al., 2000). In contrast, greater similarity between trap types in POC, mass, ${ }^{234} \mathrm{Th}$ and other elemental fluxes occurred in the Pacific (Lamborg et al., 2008). This inconsistency makes comparison of records using different traps difficult, especially when assessing uncertainties in spatially and temporally aggregated data used for regional and global budgets.

Sediment traps also miss material actively transported by vertically migrating zooplankton. This flux varies from a few to $70 \%$ of POC flux and averages between $4 \%-34 \%$ (Steinberg et al., 2000; Al-Mutairi and Landry, 2001). Variability apparently results from seasonal changes in the biomass of the vertically migrating community arising from latitudinal differences in zooplankton biomass and species composition. Sediment traps may miss other types of particles that regionally form a large component of the vertical flux. For example, larvaceans and their discarded mucous feeding webs are abundant throughout the mesopelagic and bathypelagic in some areas (Vinogradov, 2005; Robison et al., 2010). Robison et al. (2005) showed that the carbon flux due to large $(1 \mathrm{~m})$, rapidly sinking $\left(800 \mathrm{~m} \mathrm{~d}^{-1}\right)$ discarded larvacean feeding webs in the waters off Monterey Bay, California, is similar in magnitude to discrepancies between POC flux to the deep benthos and sediment oxygen demand (Smith and Kaufmann, 1999).
The collection efficiency of a trap can be assessed using radionuclides (e.g., ${ }^{234} \mathrm{Th},{ }^{230} \mathrm{Th}$ and ${ }^{210} \mathrm{~Pb}$ ) and assumptions about their behavior (e.g., steady state vs. non-steady state). For longterm deployments ( $>1$ year), moored conical traps in the upper ocean (depths $<1000 \mathrm{~m}$ ) typically undertrap by as much as $90 \%$ (Scholten et al., 2001, Yu et al., 2001; Buesseler et al., 2007). Trapping efficiencies for such traps in deep waters $(>1000 \mathrm{~m}$ ) vary between 25-160\% (Scholten et al 2001, Yu et al., 2001), suggesting an uncertainty of approximately $\pm 50 \%$ for traps in the bathypelagic. The upper $1000 \mathrm{~m}$ is generally data-poor (Boyd and Trull, 2007), and drifting cylindrical traps are recommended for this region, though they are typically deployed for only short periods (days) and may miss episodic events; a compilation of ${ }^{234}$ Th data suggests under-collection by a factor of 2 for these traps, though it may be as much as a factor of 3-10 for a single deployment (Buesseler, 1991).

Unfortunately, a trap that collects $50 \%$ of the expected ${ }^{230} \mathrm{Th}$ flux may, or may not, have the same collection efficiency for POC (Buesseler et al., 2007), because POC may be carried by particles with faster or slower average sinking velocities, and consequently have different hydrodynamic and geochemical properties. Also, individual trap calibrations are difficult to interpret because of differences between the scales of export being sampled by a single trap and those of the water column radionuclide budget (Cochran et al., 2009; Buesseler et al., 2009). However, compilations of trapping efficiency do provide a general assessment of the magnitude and direction of uncertainties associated with flux methods.

Increasing evidence suggests that spatial variations of particle export from the euphotic zone occur on smaller spatial scales than those for net primary production. Spatial scales of variability for phytoplankton are often smaller than those associated with physical processes in the ocean (Denman and Platt, 1976; Garç on et al., 2001; Siegel et al., 2008), and those for zooplankton are often smaller still (e.g., Abraham, 1998; Lévy et al., 2005). In addition, vertical plumes of high aggregate concentrations have been observed using cameras in the Eastern North Atlantic, indicating high spatial variability in sinking particle flux (Guidi et al., 2007).

Larger spatial scales of variation of POC fluxes affect the uncertainty of regional and global POC flux budgets. Laws et al. (2000) used a model based on satellite measurements of seasurface temperature and primary production to estimate a global export flux from the euphotic zone of $11.1 \mathrm{PgC} \mathrm{yr}^{-1}$. This rate

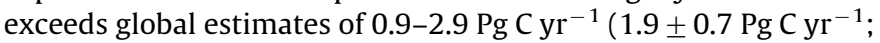
Lutz et al., 2002) based on POC flux measurements transiting 100$250 \mathrm{~m}$ depths. Global flux estimates from deep-water trap databases range from 0.34 to $0.43 \mathrm{Pg} \mathrm{C} \mathrm{yr}^{-1}$ at $2000 \mathrm{~m}$ (Lampitt and Antia, 1997; Honjo et al., 2008). Lutz et al. (2002) calculated $0.75 \pm 0.59 \mathrm{PgC} \mathrm{yr}^{-1}$ for depths between 1000 and $2000 \mathrm{~m}$; estimates of flux at depths $>3000 \mathrm{~m}$ ranged over two orders of magnitude.

POC fluxes also exhibit significant temporal variability. For example, annual fluxes at $3000 \mathrm{~m}$ in the North Atlantic showed a $49 \%$ variance (0.81-2.36 $\mathrm{g} \mathrm{C} \mathrm{m}^{-2} \mathrm{yr}^{-1}$; Lampitt et al., 2001). Strong seasonality has been observed in meso- and bathypelagic traps off Bermuda (Conte et al., 2001) and in the North Atlantic (Newton et al., 1994), with annual variation in both mass flux and percent organic carbon. Large episodic signals, unrelated to the spring bloom, have also been seen at Bermuda (Conte et al., 1998). In the mesopelagic NW Pacific, POC flux changed by a factor of $2-3$ in two trap deployments $\sim 11$ days apart, but two deployments at Station ALOHA showed very similar fluxes (Lamborg et al., 2008).

Changes in POC flux with depth are often estimated using published regression equations rather than by direct observation 
(e.g., Reinthaler et al., 2006, Baltar et al., 2009a). Such regressions include the Martin curve (Martin et al., 1987), relating flux at depth to a known flux at a given depth. This power law regression is sensitive to shallow depths, thereby biasing comparisons of fluxes in the upper mesopelagic between sites with different sampling depths (Primeau, 2006; Buesseler and Boyd, 2009). Other regressions relate flux and primary production (Antia et al., 2001), though such relationships tend to be poor (Boyd and Newton, 1999). The depth gradient of the POC flux regression provides an estimate of the POC removed by heterotrophic consumption. Unfortunately, such regressions rarely come with uncertainties for the regression parameters, making estimates of the uncertainty in flux predictions impossible. For example, Antia et al. (2001) used ${ }^{230} \mathrm{Th}$-corrected trap data from the North Atlantic to obtain a relationship between POC flux, primary productivity and depth. This relationship predicts a gradient of POC flux ( $F$ in mmol $\mathrm{C} \mathrm{m}^{-2} \mathrm{~d}^{-1}$ ) with depth ( $z$, in meters) of

$\frac{d F}{d z}=0.212 P^{1.77} z^{-1.68}$

where $P$ is the primary productivity in units of $\mathrm{mmol} \mathrm{C} \mathrm{m}^{-2} \mathrm{~d}^{-1}$. However, a difference as small as \pm 0.08 in the fitted depth exponent changes $\mathrm{d} F / \mathrm{d} z$ by a factor of 1.8 at $2000 \mathrm{~m}$, and by a factor of 2 at $4000 \mathrm{~m}$. In addition, regression relationships using functions that decrease steadily with depth may not reflect actual changes in POC flux, even in the deep ocean. For example, Lutz et al. (2002) found that measured POC fluxes measured in deep traps can often be greater than those measured at shallower depths, possibly as a consequence of a mismatch between surface regions of production and trap location (e.g., Siegel and Deuser, 1997).

The discussion above suggests that a single measurement of POC flux has an associated uncertainty factor of $\sim 2$. Uncertainties for regional and global estimates are harder to determine without understanding how they are affected by the methodology used to aggregate the data. However, the observed environmental heterogeneity suggests a conservative estimate of the uncertainty factor of 3-4.

\subsubsection{Dissolved organic carbon}

DOC ranges in biological reactivity from labile to semirefractory to refractory (Kirchman et al., 1993; Carlson and Ducklow, 1995). Concentrations are highest in the surface mixed layer and decrease with depth, the most aged, deep-ocean waters having the lowest concentrations globally (Hansell and Carlson, 1998). DOC-enriched surface water is delivered to depth by processes such as vertical pumping due to Ekman convergence in the interior of gyres or other fronts, winter-time convective overturning, and deep ocean renewal associated with thermohaline circulation. In general, greater winter mixed-layer depths lead to greater depths of DOC delivery and a longer period of sequestration for that carbon in the ocean interior. Regionally, DOC can contribute $>50 \%$ of oxygen utilization in the upper mesopelagic (depths < $500 \mathrm{~m}$; Doval and Hansell, 2000; Hansell and Carlson, 2001), although on average DOC is thought to be responsible for $<10-20 \%$ of oxygen utilization in the lower mesopelagic and in bathypelagic depths (Arístegui et al., 2002; Carlson et al., 2010).

The strength of the DOC export flux, and thus its contribution to microbial metabolism in the ocean interior, is determined by the product of two factors: the DOC concentration gradient along the path of ocean ventilation, and the rate of ventilation. The greater the gradient, the greater the load of exported DOC that is mineralized. Likewise, the greater the flux of water from the surface to the interior, the greater the role that ventilation plays in DOC export.
Uncertainty in DOC export therefore stems from uncertainties in the concentration gradients and ventilation rates. Interannual variability of the latter is particularly difficult to assess because it is likely that few of the globally important water masses have been adequately described for renewal rates. Consensus is now being reached on the magnitude of the interannual mean ventilation of the main thermocline of the North Atlantic (Hansell et al., 2007), but this ocean basin is the best studied. Estimates of ventilation of many of the major mode waters have been made (e.g., Schmitz, 1996a,b), though the uncertainty in these is likely to be at least $50 \%$ on an interannual basis. DOC concentration gradients in the major water masses are less well known than the renewal rates of those waters because of a scarcity of data. It is only in the last decade that global ocean surveys of DOC have been conducted, so much of the ocean remains under-sampled and most major water masses are not yet sampled near the regions of formation, where concentration gradients must be established.

Reducing uncertainty in DOC export estimates must begin with the best studied of the water masses. One of these is Worthington's $18{ }^{\circ} \mathrm{C}$ mode water in the western subtropical North Atlantic. As discussed above, the most important uncertainties in this system are introduced by the wide interannual variability in ventilation of the mode water along with the DOC imported during ventilation. DOC at the Bermuda Atlantic Time-series Study (BATS) site for years 2000-2003 demonstrates the interannual variability in ventilation and export (Fig. 2). During winter overturn (indicated by vertical arrows), DOC at the surface was diluted due to vertical mixing with underlying mode water. Using the $52.5 \mu \mathrm{mol} \mathrm{kg} \mathrm{kg}^{-1} \mathrm{DOC}$ concentration isoline as a guide, waters with elevated DOC deepened during overturn in 2000 and 2002 (indicating deep export), while little export occurred in the winters of 2001 and 2003. The isoline was $60 \mathrm{~m}$ deeper in 2002 (at $\sim 260 \mathrm{~m}$ ) than in 2001 (at $\sim 200 \mathrm{~m}$ ). Consequently, DOC likely played a more significant role in supporting mesopelagic heterotrophy in 2000 and 2002 than in 2001 or 2003 , demonstrating high interannual variability.

Comparisons of DOC fluxes with rates of heterotrophy raise an important timescale issue. Microbial activity (in units of mol C $\mathrm{L}^{-1} \mathrm{~d}^{-1}$ ) is determined on a daily (or hourly) basis, while DOC

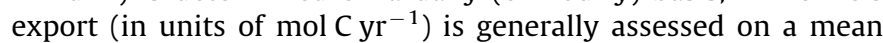
annual basis. DOC concentration gradients are established over several months or years of aging in a water mass, so the rates of DOC removal are not comparable to instantaneously determined metabolic rates. DOC removal rates following export range over 5 orders of magnitude from $\sim 1 \times 10^{-1} \mu \mathrm{mol} \mathrm{kg}{ }^{-1} \mathrm{~d}^{-1}$ in the upper thermocline at the BATS site (Hansell and Carlson, 2001), to $\sim 2 \times 10^{-4} \mu \mathrm{mol} \mathrm{kg}{ }^{-1} \mathrm{~d}^{-1}$ with NADW export (Carlson et al., 2010), to $\sim 4 \times 10^{-6} \mu \mathrm{mol} \mathrm{kg}^{-1} \mathrm{~d}^{-1}$ with ventilation of the deep

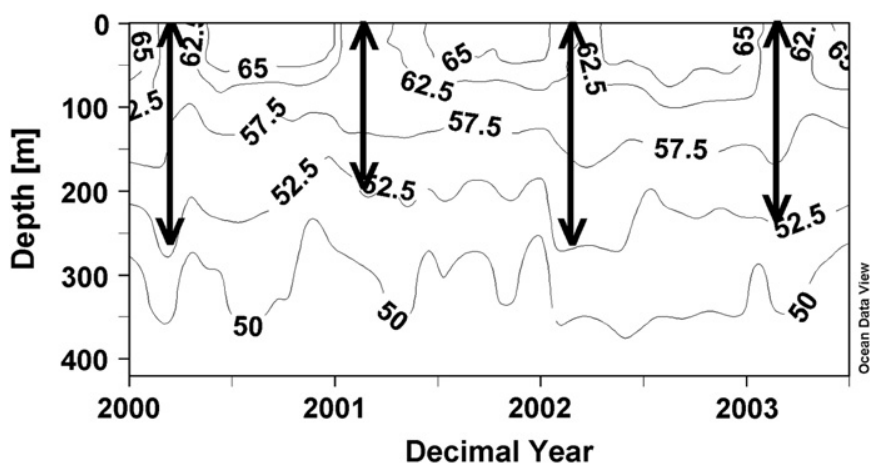

Fig. 2. DOC concentrations at the Bermuda Atlantic Time-series Station between 2000 and 2003 showing interannual variability in export. The arrows indicate winter-time downward mixing of DOC. 
Pacific via Lower Circumpolar Deep Water (Hansell et al., submitted). Most of these rates are below the detection limit of analytical methods currently used in metabolic studies.

\subsubsection{Lateral transport}

Lateral transport of organic carbon may be important for balancing midwater carbon budgets in certain regions of the ocean and may account for carbon budget imbalances in the surface waters (Michaels et al., 1994). Global estimates of lateral transport from the coastal to the open ocean vary, and depend on estimates of coastal primary production, which vary by a factor of 2 (Liu et al., 2000a; Chen et al., 2003). A comprehensive budget of the global coastal ocean by Smith and Hollibaugh (1993) indicated that $0.2 \mathrm{PgC} \mathrm{yr}^{-1}$ of terrigenous organic matter is exported to the open ocean. Liu et al. (2000b) used results from multiple coastal and ocean margins programs to estimate that $2 \mathrm{PgC} \mathrm{yr}^{-1}$ due to shelf primary production is transported globally from the continental margins to intermediate and deepocean waters. Chen et al. (2003) estimated that global net export of POC from the continental shelf was $0.34 \mathrm{Pg} \mathrm{C} \mathrm{yr}^{-1}$ while export of DOC was $0.48 \mathrm{Pg} \mathrm{C} \mathrm{yr}^{-1}$. Ducklow and McCallister (2004) generally agreed with Liu et al. (2000b), reporting a flux of $2.2{\mathrm{PgC} \mathrm{yr}^{-1}}^{-1}$ of organic carbon from the coastal to the open ocean. However, these estimates do not distinguish between lateral advection of surface POC, which should be caught by sediment traps, and lateral advection of POC at depth, which may be missed by traps.

Lateral transport may provide a significant component of the mesopelagic carbon budget in the central Arabian Sea and regions of the North Atlantic. In the former, lateral advection of suspended and/or dissolved organic matter from coastal blooms could provide sufficient organic matter to reconcile carbon budgets (Naqvi and Shailaja, 1993, Naqvi et al., 1993, Somayajulu et al., 1996). In the Canary Current region of the North Atlantic laterally advected suspended POC could account for $28-59 \%$ of the total mesopelagic respiration (Alonso-González et al., 2009).

\subsubsection{Slowly settling particles}

Sediment traps may not account for populations of slowly (e.g., $<5 \mathrm{~m} \mathrm{~d}^{-1}$ ) settling particles (Trull et al., 2008; Arístegui et al., 2009). South of the Canary Islands, such particles contributed $<5 \%$ of the total POC flux measured in the upper mesopelagic during January to May, but $>50 \%$ during June to December (I. Alonso-González unpubl.; Arístegui et al., 2009). Very little is known about the dynamics of such particles. They are part of a continuum from DOC to rapidly settling POC and interact with colloidal and rapidly settling POC through physical processes such as aggregation and disaggregation (Burd and Jackson, 2009). These slowly settling particles are presumably consumed by bacteria and ingested by filter-feeding metazoans and so contribute to regional carbon budgets (Baltar et al., 2009a; Arístegui et al. 2009).

\subsection{Carbon sinks}

\subsubsection{Bacterial carbon demand}

Estimates of bacterial carbon demand $(B C D)$ can be made from measurements of net bacterial productivity $(B P$, bacterial biomass synthesis) and respiration (BR), or $B P$ and $B G E$ (e.g. Ducklow, 2000)

$B C D=B P+B R=\frac{B P}{B G E}$ $B G E$

Similarly, bacterial respiration can be obtained from $B P$ and

$B R=(1-B G E) \frac{B P}{B G E}$

where the sources of uncertainty are $B G E$ and the conversion factors used in calculating $B P$. Deep-ocean microbial activities have, until recently, been reported as bacterial activities. However, such measurements are in fact measures of prokaryotic heterotrophic activity. In what follows, we will refer to bacterial activities but it should be realized that the numbers reflect prokaryotic activities.

Bacterial production is most commonly estimated by measuring cell incorporation rates of radioisotope-labeled leucine or thymidine (Ducklow, 2000). The major uncertainties in both approaches lie with the conversion factors used to calculate BP. For a given thymidine incorporation rate, estimates of $B P$ can range by a factor of more than 20 , depending on the thymidine:carbon conversion factor and cell carbon content used (e.g., Robinson, 2008; Nagata et al., 2010). Different methods used to calculate the conversion factor lead to differences in estimated BP of an order of magnitude (Table 4 in Ducklow, 2000) while measured conversion factors can vary by over an order of magnitude depending on location and depth (Sherry et al. 2002, Alonso-Sáez et al., 2007). Much of the variation in measured conversion factors may result from changes in the bacterial community and environmental factors, as well as from immediate respiration of the assimilated radio-labeled substrate (AlonsoSáez et al., 2007). It is important to note that more is known about variation of these parameter values in surface waters than in the dark ocean (Nagata et al., 2010).

Bacterial respiration can be estimated from direct measurements of oxygen consumption (assuming a stoichiometry of oxygen consumed to $\mathrm{CO}_{2}$ produced), direct measurements of $\mathrm{CO}_{2}$ production or DOC removal (Carlson et al., 1999) or indirectly by determination of the activity of the electron transport system (ETS; Packard, 1971). Direct measurements of oxygen consumption might not be sufficiently sensitive for the bathypelagic, given geochemical estimates of $<0.0002 \mathrm{mmol} \mathrm{O}_{2} \mathrm{~m}^{-3} \mathrm{~d}^{-1}$ (Fiadeiro and Craig, 1978; Munk, 1966; Broecker et al., 1991). However, directly measured oxygen consumption rates equivalent to $0.01-$ $0.3 \mathrm{mmol} \mathrm{C} \mathrm{m} \mathrm{C}^{-3} \mathrm{~d}^{-1}$ have recently been made in the North Atlantic (Arístegui et al., 2005b; Reinthaler et al., 2006). An important point to note here too is that the $\mathrm{O}: \mathrm{C}$ ratio may be sensitive to the oxidation state of the DOM (C. Hopkinson, pers. Comm.)

Most estimates of deep-water microbial respiration are derived from measurements of respiratory ETS activity. However, such measurements represent a potential respiration rate because the method estimates the maximum overall activity of the enzymes associated with the respiratory ETS (in both eukaryotic and prokaryotic organisms) under substrate saturation. Hence, it is necessary to convert the enzymatic ETS respiratory activities to respiration rates using a conversion factor (the R:ETS ratio).

An R:ETS $=0.09$ is commonly used in the dark ocean (Arístegui etal., 2003; Nagata et al., 2010), though higher values of $0.68 \pm 0.11$ and 5.3 have recently been reported for actively growing mesopelagic prokaryote assemblages (Arístegui et al., 2005b; Reinthaler et al., 2006, respectively). The commonly used low value was obtained from empirical relationships between ETS activity and $\mathrm{O}_{2}$ consumption rates determined in vitro from monospecific cultures of bacteria in their senescent phase and has been suggested to be representative of dark ocean communities (Christensen et al., 1980; Packard et al., 1988). Uncertainties in the parameter values resulted in an uncertainty 
in the rate of metabolically produced $\mathrm{CO}_{2}$ of $31-38 \%$ (Packard et al., 1988).

Bacterial respiration can also be estimated from $B P$ if $B G E$ is known (Equation 2). BGE is derived from the ratio between anabolic and catabolic processes and measured values vary from $<0.01$ to $>0.6$, with generally lower values expected for the dark ocean (del Giorgio and Cole, 2000). In the North Atlantic, growth efficiencies below $200 \mathrm{~m}$ averaged $0.02 \pm 0.01$ (Reinthaler et al., 2006), but higher values (0.13-0.18) were found in the subtropical North Atlantic mesopelagic near the Canary Islands (Arístegui et al., 2005b) where deep lateral advection of POC is a striking feature. In the Sargasso Sea, experiments designed to simulate DOM export and subsequent consumption by mesopelagic microbes resulted in a $B G E$ ranging from $0.5-0.13$ (Carlson et al., 2004). However, for dark ocean prokaryotic communities, few data exist from which to derive any solid conclusions about BGE variability and uncertainty (Table 1).

BGE depends on a variety of factors (Carlson et al., 2007). Attempts have been made to predict it from simple measurements such as bacterial production (del Giorgio and Cole 1998, 2000; Robinson, 2008) and temperature (Rivkin and Legendre, 2001). Scatter in the data resulted in an 8-fold range of predicted BGE values for the latter relationship (Robinson, 2008). BGE also varies with the availability of substrates for growth (López-Urrutia and Morán, 2007) and with the cost of exoenzyme synthesis, the latter resulting in a difference in BGE for attached and free-living bacteria (Anderson and Tang, 2010). In the subtropical Atlantic and the Mediterranean Sea, utilization of refractory deep-ocean organic matter was linked to higher cellspecific extracellular enzymatic activity and respiration, lower cell-specific production and decreased prokaryotic growth yield than in surface waters (Baltar et al., 2009b; Tamburini et al., 2002, 2009b).

There is also a close, dynamic coupling between particleattached and free-living microbial communities that is not well understood (e.g., Kiørboe et al., 2003) and microbial incubations may be distorting production measurements (Ploug and Grossart, 1999). Particle-attached microbes hydrolyze and consume particulate material, with up to $20 \%$ of the particulate amino acids being lost per day (Smith et al., 1992; Kiørboe and Thygesen,
2001). Most of the hydrolyzed material diffuses out of the particle to form a plume consumed by free-living microbes (e.g., Kiørboe and Jackson, 2001; Jackson and Kiørboe, 2004). This bacterial activity varies with depth and can promote particle disaggregation within the mesopelagic (Turley et al., 1995). However, the capacity of bacteria to degrade organic carbon and ballast material (e.g., opal) decreases with increasing pressure (Tamburini et al., 2006, 2009b).

Attempts to reconcile BCD with POC flux in the dark ocean are inconclusive. Early studies generally estimated BCD using measurements of bacterial production and an assumed BGE. For example, Cho and Azam (1988) assumed a BGE $=0.5$ and estimated that integrated $B C D$ between 110 and $1000 \mathrm{~m}$ in the North Pacific gyre was similar to the flux of sinking POC at $110 \mathrm{~m}$. In contrast, Simon et al. (1992) estimated that BCD integrated between 80 and $600 \mathrm{~m}$ in the subarctic Pacific was $137-172 \%$ of POC supply, assuming a $B G E=0.3$. At the same location, Boyd et al. (1999) estimated $B R$ from $B P$, finding that it was 4-10 fold higher than POC supply depending on whether the assumed BGE was 0.4 or 0.1 , respectively. Anderson et al. (2007) estimated that the BCD of mesopelagic biota in the anoxic zone of the central Arabian Sea could be met by the vertical supply of sinking detritus, assuming that $\mathrm{BGE}=0.27$. If, however, a lower $\mathrm{BGE}=0.10$ was used, the carbon budget would be difficult to balance without invoking an external source of organic carbon such as lateral advection of particles or DOC from outside the study area (Anderson and Ryabchenko, in press). The choice of BGE is clearly crucial; the low BGEs suggested by some recent studies (Reinthaler et al., 2006; Alonso-Sáez et al., 2007; Baltar et al., 2009a) increase estimates of BCD, thus increasing the potential for $\mathrm{BCD}$ to exceed POC supply is obvious.

\subsubsection{Zooplankton carbon demand}

Measurements of zooplankton respiration and carbon demand in the meso- and bathypelagic are limited and suffer from methodological constraints. Many animals do not survive the sampling and decompression when caught at deep-water temperatures and transported through the warm epipelagic zone, especially in non-polar regions. Some direct respiration

Table 1

Commonly used and estimated ranges for parameters used in calculating dark ocean carbon imbalances.

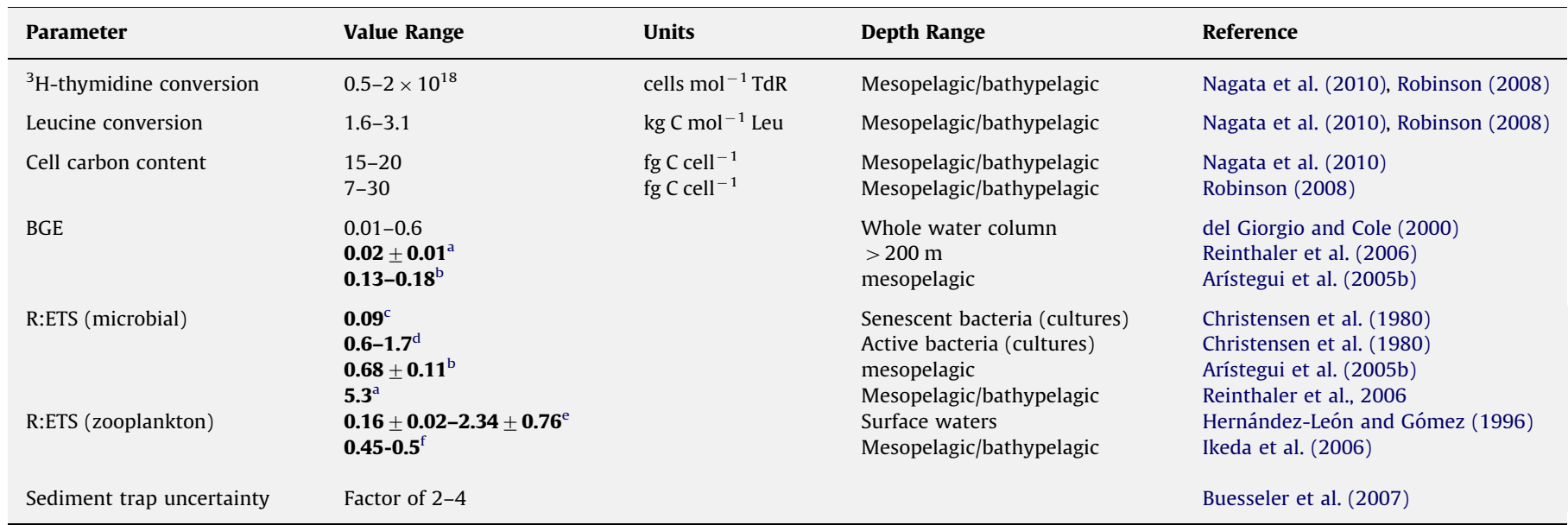

Bold figures represent values measured in specific locations or measured from laboratory cultures. Other values represent ranges found in the literature.

a Measurements made in the eastern and western North Atlantic.

${ }^{b}$ Measurements made in the subtropical Northeastern Atlantic.

${ }^{\mathrm{c}}$ Measurements from culture with cells in senescent phase.

d Measurements from culture with cells in the exponential growth phase.

e Surface waters from the tropical Atlantic Ocean, Baltic Sea, Bransfield Strait (Antarctic Peninsula), and waters off the Canary Islands.

${ }^{\mathrm{f}}$ Compilation of global measurements. 
measurements, made with manned submersibles, exist from mesopelagic depths in the Atlantic Ocean (Bailey et al., 1994), from benthopelagic depths in the Pacific Ocean (Smith, 1982, 1985; Smith et al., 1986), and from the meso- and bathypelagic zones for certain taxa such as copepods (Thuesen et al., 1998; Ikeda et al., 2006) and medusae (Thuesen and Childress, 1994). Measured in situ weight- and carbon specific respiration rates for mesopelagic gelatinous animals were 2-5 times higher than shipboard measurements of the same species (Bailey et al., 1994). If such differences turn out to be common, then a recalibration of metazoan respiration based on in situ measurements could re-define the known levels of zooplankton carbon demand.

Measurements of metabolic activity under in-situ conditions are technically difficult (Tamburini et al., 2009a, 2009b). Zooplankton respiration is increasingly measured using either the ETS method (e.g., Hernández-León and Gómez, 1996; Koppelmann et al., 2000) or allometric relationships combined with measurements of zooplankton biomass (e.g., Ikeda et al., 2007; Steinberg et al., 2008), though oxygen consumption may depend on motion and feeding mode as well as body weight and temperature (Paffenhöfer, 2006). Zooplankton ETS measurements are subject to similar uncertainties as those for bacteria. For example, R:ETS for shallow-water copepods varies from $0.16 \pm 0.02$ to $2.34 \pm 0.76$ with typical uncertainties ranging from 10 to $50 \%$ (HernándezLeón and Gómez, 1996). Allometric estimates of zooplankton respiration from biomass suffer from the same problem as regressions of POC flux with depth; few published relationships give uncertainties for regression coefficients, making an evaluation of the uncertainties of predicted respiration rates impossible. In addition, allometric relationships have largely been determined only for epipelagic zooplankton (Ikeda, 1985) and for certain taxa such as copepods (Ikeda et al., 2007), and may not be appropriate for use with meso- and bathypelagic taxa. Conversion of zooplankton respiration to carbon consumption (total zooplankton carbon demand) requires assumptions about the fraction of assimilated carbon respired and the assimilation efficiency (Steinberg et al., 1997, 2008), each carrying their own uncertainties.

The relative contribution of zooplankton to the decrease in POC flux varies spatially and temporally. Steinberg et al. (2008) estimated that mesopelagic zooplankton and bacteria in the subarctic Pacific (at station K2) contributed approximately equally to the carbon demand, whereas BCD exceeded that of zooplankton in the subtropical Pacific (at the Hawaii Ocean Timeseries (HOT) station ALOHA). Sinking POC flux was inadequate to meet the carbon demands of bacteria and zooplankton at both sites (Fig. 3). Zooplankton $\mathrm{C}$ demand in the bathypelagic varies by a factor of 2-20 depending on region and season, with the greatest variability in the upper bathypelagic (1000-2500 m) (Koppelmann and Frost, 2008). Mesozooplankton respiration has been estimated to account for 7-66\% of the loss of sinking POC flux in the bathypelagic, again depending on region and season, with the lowest values and variability occurring in the Arabian Sea (Koppelmann and Weikert, 1999; Koppelmann et al., 2000, 2004). This spatial and temporal variability increases uncertainty in regional and global budgets.

Estimates of microzooplankton carbon demand in the mesoand bathypelagic ocean are rare and sorely needed. In the northwest Mediterranean, the abundance of heterotrophic nanoflagellates between 5 and $2000 \mathrm{~m}$ was observed to decrease by three orders of magnitude and showed little seasonality (Tanaka and Rassoulzadegan, 2002). The biomass of pico- and microplankton in the North Pacific also decreases with depth (Yamaguchi et al., 2002; Sohrin et al., 2010). Mesopelagic microzooplankton respire, on average, $18-76 \%$ of the POC flux remaining at $250 \mathrm{~m}$ in the Arabian Sea (Gowing et al 2003). To our

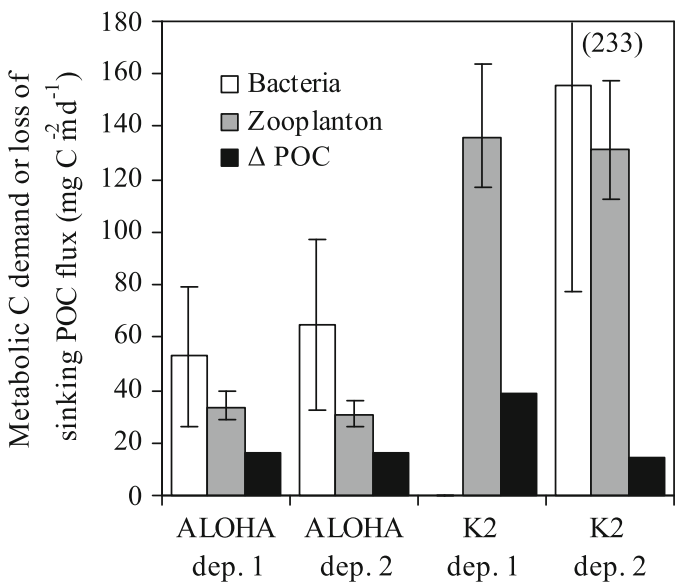

Fig. 3. Metabolic carbon demand and loss of sinking POC at stations ALOHA and K2 as measured during the VERTIGO program (figure from Steinberg et al, 2008).

knowledge, no other studies report microzooplankton $\mathrm{C}$ demand in the dark ocean, adding to our uncertainty of their role in deepsea carbon budgets.

The feeding strategies and behavior of many meso- and bathypelagic zooplankton differ from their epipelagic counterparts, with some depending on sinking POC and others using suspended POC or bacteria as food sources (e.g., Wishner et al., 2000; Koppelmann et al., 2009). This selectivity directly affects their metabolism and the ways in which we estimate their contribution to remineralization. A significant fraction of the mesopelagic zooplankton $C$ demand could be met by spatially uncoupled organic $C$ consumption by vertically migrating zooplankton in surface waters and metabolism at depth (Steinberg et al., 2008); this is likely the case for vertically migrating micronekton as well. This active transport was estimated to support between 15 and $88 \%$ of the observed zooplankton respiratory carbon demand between 150 and $1000 \mathrm{~m}$ at stations ALOHA $\left(22^{\circ} 45^{\prime} \mathrm{N}, 158^{\circ} \mathrm{W}\right)$ and $\mathrm{K} 2\left(47^{\circ} \mathrm{N}, 160^{\circ} \mathrm{E}\right)$ in the Pacific, but active transport of DOC (by excretion at depth) was only able to support $1-7 \%$ of the estimated bacterial carbon demand. Likewise, gelatinous grazers may also be short-circuiting the vertical flux measured by sediment traps. Vertically migrating salps ingest POC near the surface, releasing it as larger fecal pellets at their daytime depths (Wiebe et al., 1979; Phillips et al., 2009). Because the POC has been repackaged into larger, faster-sinking pellets released at greater depth, it is less likely to be caught in traps or remineralized in the water column. Ontogenetic (seasonal) vertical migration is also important in some abundant subpolar copepod species, representing a significant $\mathrm{C}$ export to depth (Kobari et al. 2003; Robinson et al., 2010; Robison et al., 2010).

\subsubsection{Metazooplankton, micronekton and top predators}

As noted by del Giorgio and Duarte (2002), few estimates of respiration exist for metazooplankton and (top predator) vertebrates in the deep ocean. Those authors cite the metazooplankton contribution to respiration as varying from $<1 \%$ to $>50 \%$. To estimate the contribution of vertebrates, the authors assumed a minimum of three trophic levels between vertebrates and primary producers, with an assumed transfer efficiency of $10 \%$ between each level. These assumptions led to the conclusion that vertebrate respiration is $\leq 1 \%$ of the total open ocean respiration. Any uncertainty in such a small contribution is unlikely to affect the overall dark ocean carbon budget. 


\subsubsection{Other estimates of remineralization}

Various methods of measuring $\mathrm{O}_{2}$ consumption rates have been used to estimate rates of remineralization in the dark ocean. Andersson et al. (2004) used global ocean hypsometry combined with sediment respiration values to obtain patterns of particulate carbon flux. This study suggested a global respiration in waters $>200 \mathrm{~m}$ of $7.4{\mathrm{PgC} \mathrm{yr}^{-1}}^{-1}$, significantly lower than the $21-28 \mathrm{Pg}$ $\mathrm{C} \mathrm{yr}^{-1}$ estimated by del Giorgio and Duarte (2002), but more in line with the values of export production in the open ocean predicted from the model by Laws et al. (2000). The results of this model can be questioned, but are in broad agreement with other, similar models (Boyd and Trull, 2007). However, estimates of mesopelagic respiration made by extrapolating areal rates of ETS activity (Arístegui et al., 2003) give values higher than those obtained by Andersson et al. (2004), partly because using sediment respiration considers only particulate material fallen on the sediment, whereas the ETS method considers respiration of both dissolved and particulate material. Andersson et al. (2004) showed only modest influence of the sediment, as opposed to Jahnke and Jackson (1987) and Jahnke (1996), and this was attributed to the earlier study including data from productive regions such as the Arabian Sea and upwelling areas near Africa and South America. However, separating the effects of euphotic zone, mesopelagic and bathypelagic processes on export flux remains problematic (Boyd and Trull, 2007).

Estimates of mesopelagic remineralization and its variability can also be obtained using the particulate Ba-barite tracer as a proxy (Dehairs et al., 1992, 1997, 2008). This approach is in good agreement with POC decreases determined from sediment traps (Dehairs et al., 2008). Shopova et al. (1995) and Dehairs et al. (1997) report $\mathrm{O}_{2}$ consumption rates for the mesopelagic Southern Ocean of 1-5.8 $\mathrm{mmol} \mathrm{O}_{2} \mathrm{~m}^{-2} \mathrm{~d}^{-1}$ (mean: $2.5 \mathrm{mmol} \mathrm{O}_{2} \mathrm{~m}^{-2} \mathrm{~d}^{-1}$ ). These values were obtained from $\mathrm{O}_{2}$ profiles and a 1-D advectiondiffusion model with calculated vertical diffusivity and upwelling (downwelling) velocities. In terms of carbon $\left(\mathrm{O}_{2}: \mathrm{C}\right.$ Redfield $=1.4$ ), the mean rate is equivalent to $1.9 \mathrm{mmol} \mathrm{C} \mathrm{m}^{-2} \mathrm{~d}^{-1}$ and represents $3 \%$ of primary productivity. However, this introduces another conversion factor, the respiratory quotient, with its associated uncertainties.

Feely et al. (2004) and Karstensen et al. (2008) presented AOU rate estimates using measurements of AOU and age models (e.g., Jenkins, 1987). For the mesopelagic, the organic carbon respiration rates range from 3.1 to $7.6 \mathrm{mmol} \mathrm{C} \mathrm{m}{ }^{-2} \mathrm{~d}^{-1}$, with the average equivalent to the oxidation of $5.1 \mathrm{PgC} \mathrm{yr}^{-1}$ for the mesopelagic Pacific (Feely et al., 2004). These biogeochemical estimates agree with those of Nagata et al. (2000) who report mesopelagic BCD values (North Pacific Subarctic Pacific; 100$1000 \mathrm{~m}$ ) between 1.4 and $4.8 \mathrm{mmol} \mathrm{C} \mathrm{m}^{-2} \mathrm{~d}^{-1}$.

The observations described above suggest a convergence between results obtained via conceptually different approaches. However, many of these estimates depend on conversion parameters (e.g., R:ETS) that show considerable variability. Differences in estimates of oxygen utilization rates (OUR) obtained by various methods arise at least in part from the different timescales over which these techniques can be applied. In essence, OUR is a time-dependent variable that decreases as observational timescales increase. Various pools of organic carbon characterized by different degrees of reactivity exist, such that more labile carbon is respired immediately below the euphotic zone and more recalcitrant and refractory components persist to greater depths (Martin et al., 1993; Carlson et al., 2002; Carlson and Ducklow, 1995; Clegg and Whitfield, 1990; Kirchman et al. 1993; Kadko, 2009).

Generally, however, there is a mismatch between respiration based on OUR and that implied by the vertical attenuation of POC. We suggest this is because the OUR effectively includes and integrates processes that would not readily be captured by sediment traps, such as vertical migration of zooplankton, export and respiration of DOC, missed episodic events, lateral input of POC, trap collection inefficiency, and chemoautotrophy (for the latter, see Reinthaler et al., 2010).

\section{The uncertainty of budgets}

Given the above assessments of uncertainties in estimates of carbon sources and sinks, we can start to assess uncertainties in global and regional budgetary calculations, and those in intensive field programs.

\subsection{Global and regional budgets}

Uncertainties in global and regional budgets arise from uncertainties in the data themselves, different assumptions made in using the data, and the process of averaging and aggregating the data. The choices of which data to use, and how to weight different types of measurements, play key roles in determining the outcome of a global budget. For example, ETS-based mesopelagic respiration estimates used by Arístegui et al. (2005a) were lower than those used by del Giorgio and Duarte (2002), but higher than those based on sediment $\mathrm{O}_{2}$ consumption (Andersson et al., 2004).

Creating global budgets requires assumptions about the spatial and temporal homogeneity of relevant processes and stocks. Comparing global estimates of POC export with those of dark ocean respiration assumes that the data sets used to compile these estimates have similar spatial coverage. This is frequently not the case. Global budgets also smooth temporal variability that may be driving different processes. For example, episodic production and export of particles from surface layers could lead to temporal offsets in measurements of metabolism (i.e. yesterday's flux is today's meso- and bathypelagic metabolism), resulting in metabolic imbalances (Karl et al., 2003). Aggregating data over large spatial and temporal scales may conceal other factors driving the observed variability. For example, in the Levantine Sea, ETS values varied by more than one order of magnitude at various depths (La Ferla and Azzaro, 2001). This variability is coupled to the dynamics of the circulation and water masses in the region and thus not captured in an averaged estimate.

\subsection{Budgets from intense field studies}

Some problems inherent in aggregating and averaging disparate data sets can be overcome with intense field studies. Budgets from such studies are more consistent in showing a carbon imbalance. Lefèvre et al. (1996) measured POC flux and ETS activity in the NW Mediterranean Sea citing uncertainties in bacterial respiration of $\pm 40 \%$ ( $\pm 20 \%$ from overall measurement reproducibility and $\pm 20 \%$ from the assumed R:ETS value). The carbon budget could not be balanced within this range of values. However, their R:ETS value implicitly assumed that cells were in the senescent phase (Arístegui et al., 2005b).

The most comprehensive mesopelagic carbon budget study to date occurred during the VERTIGO (Vertical Transport in the Global Ocean) program (Steinberg et al., 2008). Fewer carbon budgets exist for the bathypelagic, and none that we are aware of measure both POC fluxes and total (microbial and zooplankton) carbon demand. Measurements of prokaryotic abundance, production (using leucine incorporation) and respiration (oxygen consumption and ETS activity) in the North Atlantic indicate an imbalance when compared with POC 
fluxes predicted using a regression relationship (Reinthaler et al., 2006). In this case, the imbalance was greatest (two orders of magnitude) in the bathypelagic.

Estimates of zooplankton carbon demand in the bathypelagic also indicate the existence of an imbalance. Koppelmann and Weikert (1999) compared estimates of zooplankton respiration in the bathypelagic NE Atlantic with estimates of POC. The available POC was only able to support zooplankton respiration during the spring; other seasons showed a deficit in POC flux.

\subsection{Budgets from models and other means}

Carbon budget imbalances can also be analyzed indirectly using models. Schlitzer (2004) developed an inverse model to determine export production using distributions of dissolved oxygen, nutrients and carbon and assuming a power law decrease of POC flux with depth. The model produced an integrated carbon export of $3 \mathrm{Pg} \mathrm{C}$ $\mathrm{yr}^{-1}$ for the Pacific Ocean north of $10 . \mathrm{S}$, agreeing with estimates based on AOU and CFC-based water-mass ages and carbon measurements (Feely et al, 2004). Interestingly, this model also reproduces quite well measurements of carbon export production made in the Equatorial and North Pacific. This agreement between measured export rates, modeled export rates and OUR suggests that carbon sources and sinks do balance in this region of the ocean. However, modeled deep-ocean carbon distributions are sensitive to the parameterization of POC flux used (Howard et al., 2006).

A three-dimensional hydrodynamic-ecosystem model was used to study the origin of organic carbon needed for production by denitrifying bacteria (Anderson et al., 2007). Model-predicted denitrification rates in the anoxic part of the mesopelagic zone were consistent with independent estimates based on calculations of nitrate deficit (Naqvi and Shailaja, 1993; Howell et al., 1997; Bange et al., 2000). Using appropriate stoichiometry, and including bacterial production in the aerobic part of the mesopelagic zone, total bacterial production was $1.92 \mathrm{mmol} \mathrm{C} \mathrm{m}^{-2} \mathrm{~d}^{-1}$, similar to a measured estimate of $2.38 \mathrm{mmol} \mathrm{C} \mathrm{m}^{-2} \mathrm{~d}^{-1}$ (Ducklow, 1993). The model showed a near balance between vertical supply of POC from the euphotic zone in the central Arabian Sea and BCD in the mesopelagic zone below. Bacterial production was, however, calculated using a BGE of 0.27 (Anderson and Williams, 1998), which one could argue is too high. A simple flow analysis model, including both bacteria and zooplankton as consumers of detritus, and BGEs of 0.081 and 0.135 for anoxic and aerobic parts of the water column respectively, showed bacteria accounting for $82 \%$ of the total respiration (Anderson and Ryabchenko, in press). However, these lower BGE values predicted that mesopelagic bacterial production was only $1.07 \mathrm{mmol} \mathrm{C} \mathrm{m}^{-2}$ $\mathrm{d}^{-1}$, much lower than the value estimated by Ducklow (1993). The authors concluded that external sources of organic matter, such as lateral transport from the western basin, might reconcile the carbon budget of the region.

A more detailed flow analysis of carbon cycling by the mesopelagic food web divides bacteria into attached and freeliving groups, and divides grazers between detritivores, bacterivores and higher zooplankton (Anderson and Tang, 2010). Bacteria dominated total community respiration, with this result being surprisingly insensitive to values assigned to parameters for BGE. Detritivores could be important consumers of POC, but the model indicated that much of what they graze could be recycled to the food web as pellets or DOC rather than respired.

\subsection{Assessing uncertainty using a Monte Carlo analysis}

It is clear that assumed values of conversion coefficients (e.g. leucine or thymidine conversion factors, BGE etc) play crucial roles in estimating metabolic activity and, hence, determining the existence and magnitude of a budget imbalance. To quantitatively assess the influence that parameter ranges have on the size of a budget imbalance, a Monte Carlo analysis was performed using bacterial $\left[{ }^{3} \mathrm{H}\right]$-thymidine incorporation rates from the VERTIGO program (Steinberg et al. 2008). Data from three deployments were chosen for this analysis: ALOHA 1, ALOHA 2, K2 2 (Fig. 3. and Steinberg et al., 2008). Various literature ranges were used for the $\left[{ }^{3} \mathrm{H}\right]$-thymidine incorporation conversion factor $(\tau)$, the carbon content per cell $\left(f_{c}\right)$ and the BGE. Values for each parameter were sampled from uniform distributions, with ranges given by the minimum and maximum value for that parameter. Bacterial carbon demand was calculated using Equation (1), and measured POC fluxes were assumed to be uncertain by a factor of 2 (Section 2.1.1). The ratio of available $\mathrm{POC}(\triangle \mathrm{POC})$ to $\mathrm{BCD}$ was calculated for each Monte Carlo trial, so $\triangle \mathrm{POC} / \mathrm{BCD}>1$ indicates no carbon budget imbalance. Four sets of parameter ranges were chosen, and 10,000 separate trials were used for each parameter set (Fig. 4).

There was a negligible probability of $\triangle \mathrm{POC} / \mathrm{BCD}>1$ for the ranges of parameter values used by Steinberg et al. (2008) (Fig. 4a). However, up to a $45 \%$ probability of having $\triangle \mathrm{POC} /$ $\mathrm{BCD}>1$ was obtained by choosing a wider range of values taken from the literature. Two parameters stand out as being important; the BGE and the carbon content of a cell (see figure caption). Increasing the maximum BGE from 0.2 to 0.46 increased the probability of $\triangle \mathrm{POC} / \mathrm{BCD}>1$ for the ALOHA 1 deployment from $5 \%$ to $26 \%$ - the corresponding probabilities for the other deployments also increased (Fig. 4b,c). Decreasing the upper limit of $f_{c}$ further increased the probability of having $\triangle \mathrm{POC} / \mathrm{BCD}>1$ during the ALOHA 1 deployment to 45\%, with corresponding increases for the other two deployments (Fig. 4c,d).

The frequency distributions for the two deployments at station ALOHA are very similar, and distinct from that for the K2 deployment. In all four cases, the $\mathrm{K} 2$ distribution has a maximum value in the range $\triangle P O C / B C D=0.1-0.5$, and drops sharply for higher $\triangle \mathrm{POC} / \mathrm{BCD}$ values. Distributions for both ALOHA deployments are broader, with a decrease in the maximum value $f_{c}$ markedly broadening the distribution (Fig. 4c and d).

\section{Conclusions and recommendations for future research}

An increasing number of intense field studies suggest an imbalance exists between organic carbon sources and sinks in the dark ocean (Boyd et al., 1999; Reinthaler et al., 2006; Steinberg et al., 2008; Baltar et al., 2009a). Elucidating the reasons for this will require combining research from different disciplines (Table 2).

\subsection{Parameter values and uncertainties}

A large source of uncertainty lies in the values of conversion factors and parameters used to estimate metabolic activity. Much of our knowledge about these parameters comes from surface measurements (Robinson, 2008; Sherry et al., 2002; Alonso-Saéz et al., 2007), and very little is known about their variability in the dark ocean or what drives variation there. The few measurements that exist indicate a smaller variation of growth efficiencies in the meso- and bathypelagic than at the surface (Reinthaler et al., 2006; Arístegui et al., 2005b). BGE can be affected by factors such as nutrient stress, DOC quality, viral activity and bacterial diversity (e.g., Boyd et al., 1999; Carlson et al., 2007 and references therein). Conversion factor values appropriate for organisms in the deep ocean urgently need to be determined and the causes of variation understood. If conversion factors are not measured concurrently with metabolic activity, then carbon demands should be estimated either using a range of literature 


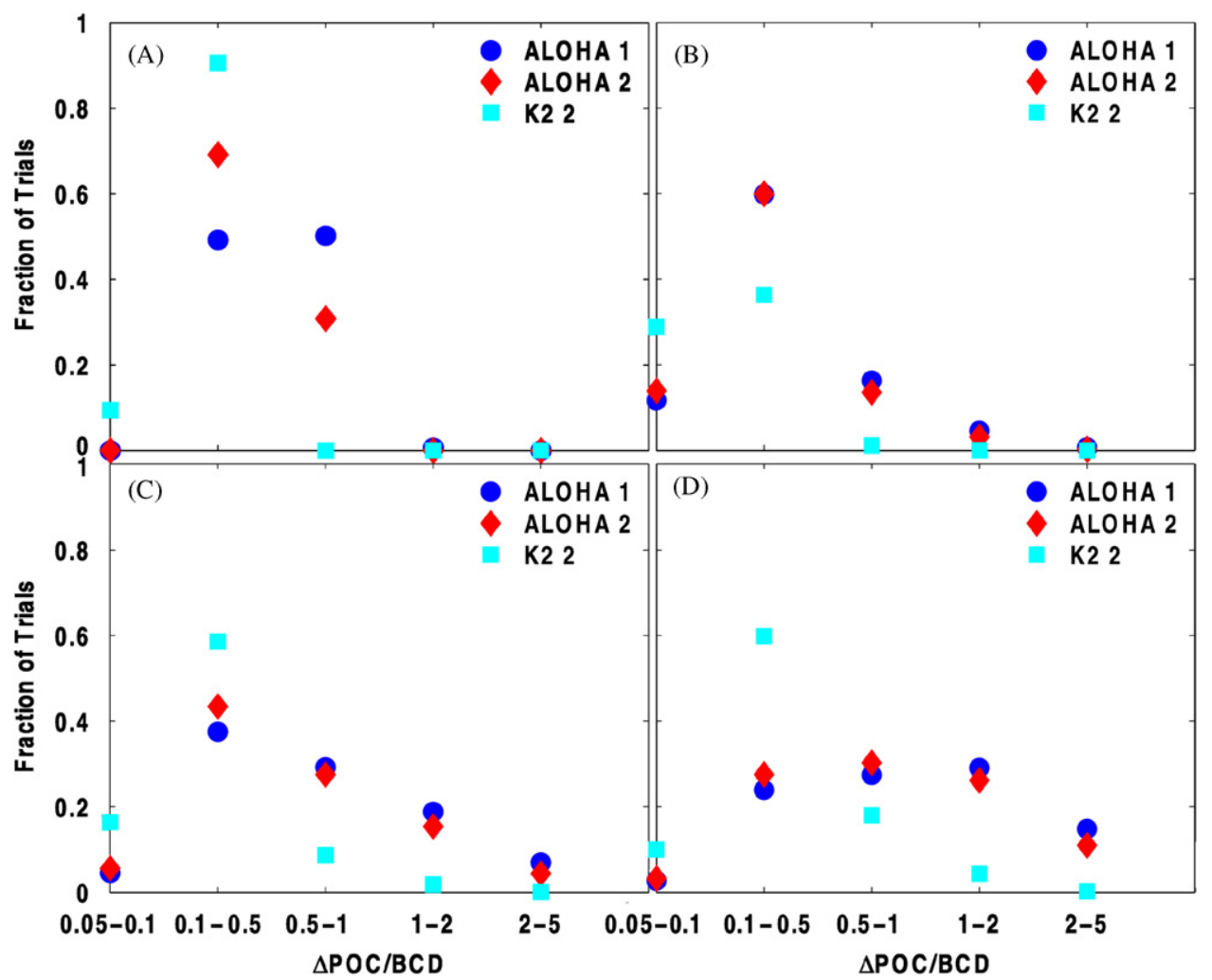

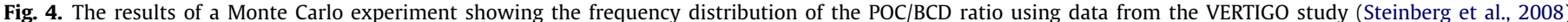

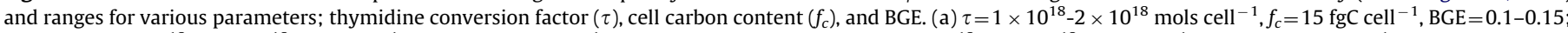

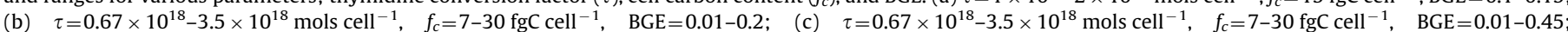

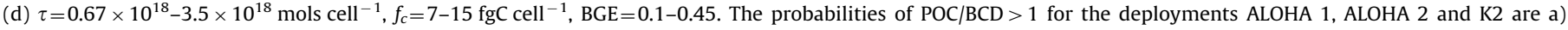
$<1 \%$, < $1 \%$, < $1 \%$; b) $5 \%, 3 \%$, < $1 \%$; c) $26 \%, 20 \%, 2 \%$; d) $45 \%, 37 \%, 5 \%$ respectively.

Table 2

Table of recommendations for future research and techniques.

\begin{tabular}{|c|c|c|}
\hline Category & Recommendation & Sections \\
\hline \multirow[t]{4}{*}{$\begin{array}{l}\text { Concepts \& } \\
\text { Analysis }\end{array}$} & $\begin{array}{l}\text { Better conceptual approaches and more accurate estimates of metabolic activity conversion factors/parameters and their } \\
\text { variability. }\end{array}$ & $2.2 .1 ; 3 ; 3.4 ; 4.1$ \\
\hline & Providing uncertainties for regression parameters. & $2.1 .1 ; 2.2 .3$ \\
\hline & Examination of correlations between geochemical and ecological estimates of metabolic activities. & 4.3 \\
\hline & Consensus on depth domain boundaries. & 4.3 \\
\hline \multirow[t]{3}{*}{ Sampling } & Understand role of pressure in measurements of metabolic activity & 2.2 .3 \\
\hline & $\begin{array}{l}\text { Sampling of presently unquantified \& under-sampled sources/sinks (e.g. lateral advection, suspended particles, } \\
\text { microzooplankton, viruses, migrants, stochastic events) and processes (coprophagy, vertical transport etc.). }\end{array}$ & $\begin{array}{l}2.1 .1 ; 2.1 .3 ; 2.2 .3-4 ; \\
3.2 ; 4.2\end{array}$ \\
\hline & Accounting for temporal \& spatial scale mismatches in sources and sinks. & $2.1 .1 ; 2.1 .2 ; 4.3$ \\
\hline \multirow[t]{2}{*}{ Processes } & Understanding role of food-web dynamics/community structure, linking diversity and function with environmental variability. & $2.2 .3 ; 2.2 .4 ; 4.3$ \\
\hline & Investigate new processes \& novel metabolic pathways (e.g. chemosynthesis as C source) & 4.3 \\
\hline \multirow[t]{2}{*}{ Models } & Process oriented models of particle flux attenuation & $4.2-4.3$ \\
\hline & Meso and bathy-pelagic food web/community structure models & $4.2-4.3$ \\
\hline
\end{tabular}

values (e.g., Boyd et al., 1999; Steinberg et al., 2008) or alternative techniques (such as a Monte Carlo analysis). Our analysis used uniform distributions to sample parameter values, but different sampling distributions (e.g., normal, log-normal, Poisson) would allow a priori information of the most likely range of parameter values to be incorporated. It is also worth noting that estimates of BGE obtained from $\mathrm{O}_{2}$ consumption, $\mathrm{CO}_{2}$ consumption or DOC utilization using closed systems may give low estimates of BGE because the substrate becomes more recalcitrant over the course of the experiment (C. Carlson, pers. comm.). A comparison of the experiment duration and the timescale for microbial organisms to find fresh substrate in the environment should help determine if this is indeed a problem.

The use of regression-based relationships should be considered carefully because, without uncertainties for the regression parameters, it is difficult to quantify uncertainties in predicted values. We strongly recommend that regression relationships (such as those for allometric relationships and POC flux attenuation vs. depth) be supplied with uncertainties for the regression parameters. In addition, agreement must be reached on how to standardize POC flux measurements and parameterizations (e.g., by normalizing POC flux to the depth of the local euphotic zone (Buesseler and Boyd, 2009), so that budget comparisons can be made more precisely.

We need to determine the role of pressure in the measurement of metabolic activities. Measurements of bacterial metabolic activity in deep NW Mediterranean waters were greater at in situ pressures compared with those made under decompressed conditions and BGEs determined under decompressed conditions 
may underestimate in situ BGE values (Tamburini et al., 2003, 2009a; Nagata et al., 2010). Measurements of ${ }^{14} \mathrm{C}$-glutamic acid uptake indicate an increased energy cost associated with decompression, suggesting BGEs determined under decompressed conditions may underestimate in situ values (Tamburini et al., 2003). In contrast, pressure can inhibit the metabolic activities of attached-to-particles bacteria when they sink through the water column of the mesopelagic zone (Tamburini et al., 2006, 2009b). Pressure can affect biochemical processes (Somero et al., 1983) and is known to affect thymidine incorporation rates in surficial sediments (Dixon and Turley, 2000).

\subsection{Unquantified sources}

The contribution of slowly settling particles to the organic carbon of the dark ocean remains largely unquantified (AlonsoGonzález et al., 2009), and may make up the carbon imbalance (e.g., Baltar et al., 2009a; Arístegui et al., 2009). However, if this material originates from sinking POC (e.g., through particle disaggregation) then it should be accounted for using radiotracer proxies such as ${ }^{234} \mathrm{Th}$ (assuming ${ }^{234} \mathrm{Th}$ faithfully traces all POC fractions). If so, the suspended material in the dark ocean may have originated from POC that settled into the mesopelagic, or was advected into the area, some time prior to the flux measurements being made. Alternatively, the suspended material may form from spontaneous aggregation of micro-gels (Verdugo and Santschi, 2010). The original source of the organic carbon would have been DOC or sinking POC and there is a time-scale and spatial-scale issue. In either case, long-term measurements of POC fluxes and metabolic activity, combined with mechanistic models of suspended particulate material, may result in balanced budgets.

\subsection{Processes and dynamics in the dark ocean}

The boundaries of the meso- and bathypelagic are usually specified using given depths. For example, the mesopelagic is usually considered to extend from 100 to $1000 \mathrm{~m}$, but may not capture changes in processes characteristic of the region. For example, the upper limit of the mesopelagic might be better defined as the base of the euphotic zone (Buesseler and Boyd 2009), distinguishing regions of net particle production and heterotrophic consumption. Alternatively, net particle production and the rate of particle loss from sinking could be used, though this would give a highly dynamic boundary that would depend on biological processes (e.g., primary production), physical particle processes (e.g., coagulation), and physical oceanographic processes (e.g., changes in mixed-layer depth; Jackson, 2008). As a community, we need to reach consensus on the definitions of the boundaries of the meso-, bathy- and abyssopelagic.

Food-web dynamics in the dark ocean is less well understood than that in the euphotic zone. Important issues include the relative roles of bacteria and zooplankton in cycling carbon in the dark ocean (Steinberg et al., 2008; Anderson and Tang, 2010) and the response of zooplankton populations to changes in largerscale hydrographic features (Koppelmann et al., 2004) and changes in food supply (Koppelmann and Weikert 2007). Gelatinous animals are a major component of midwater pelagic biomass (Wiebe et al., 1979; Robison, 2004) but are seriously under-sampled by conventional methods (Madin et al., 1994; Bailey et al., 1994; Haddock; 2004; Robison et al., 2010) and their effect on vertical carbon flux, midwater food-webs and community respiration remains unclear. Micronekton are also not usually included in meso- and bathypelagic respiration budgets, but some information on their respiration and carbon transfer is available
(Robison and Bailey, 1981; Childress and Thuesen, 1992; Childress, 1995).

Biological oxidation processes are usually regarded as being responsible for the removal of exported DOC. However, there is little direct evidence that microbes are the sole or primary agents responsible for this. Correlations between DOC and AOU suggest that DOC supports some of the total oxygen utilization rate (Doval and Hansell, 2000; Hansell and Carlson, 2001; Arístegui et al., 2002). But, because of the mismatch in time scales between DOC and microbial activity measurements, the linkage between microbial activity and DOC removal is not absolutely certain. Abiotic processes could well be agents for DOC removal (Verdugo and Santschi, 2010), in which case some part of the observed correlation with AOU would exist by coincidence rather than as a result of DOC oxidation. Chemoautotrophy may also play a significant role in the meso- and bathypelagic, thereby affecting the carbon budget (Reinthaler et al., 2010). It is probable that microbes are dominant in DOC removal, but confirmation of their role in the ocean interior would be valuable.

Comparisons between sources and sinks often assume steady state. However, many types of measurement used in such comparisons have timescales that may not be compatible with others. For example, bacterial abundance varies with long-term means in POC flux, but less so with episodic events (Nagata et al. 2000, 2010; Hansell and Ducklow, 2003) and local-scale microbial respiration rates derived from bottle incubations will likely differ from regional-scale oxygen utilization rates derived from oceanic oxygen fields combined with tracer studies.

Many of these issues can be addressed by combining modeling with intensive field programs that measure as many relevant parameters as possible. It is imperative that the spatial and temporal scales of carbon sources (POC, DOC, suspended particles) and sinks (organism carbon demand) be assessed and measurements made over compatible scales. Such programs should try to reconcile biogeochemical and ecological estimates over their relevant timescales and spatial scales. A close integration of field programs with a variety of modeling approaches (e.g., large-scale biogeochemical models, food-web models, small-scale mechanistic models, and novel modeling approaches) will aid with the interpretation of field data and investigation of processes important to the dark ocean.

\section{Acknowledgments}

This manuscript developed from discussions during the first IMBER IMBIZO held in Miami in November 2008. We thank all those who took part in the meeting and its organization, including the IMBER International Project Office, the organizing committees and the session chairs. We also thank Phil Boyd, Craig Carlson, and Dave Siegel whose comments greatly improved the manuscript. $A B B$ received financial support from the National Science Foundation (OCE-0645485), J.A. was supported by the CAIBEX (CTM2007-66408-C02-02/MAR) project and C.T. was supported by the ANR-POTES (ANR-05-BLAN-0161-01) program supported by the Agence Nationale de la Recherche (France).

\section{References}

Abraham, E.R., 1998. The generation of plankton patchiness by turbulent stirring. Nature 391, 577-580.

Alonso-González, I.J., Arístegui, J., Vilas, J.C., Hernández-Guerra, A., 2009. Lateral POC transport and consumption in surface and deep waters of the Canary Current region: a box model study. Global Biogeochemical Cycles 23, GB2007, doi:10.1029/2008GB003185.

Alonso-Sáez, L., Gasol, J.M., Arístegui, J., Vilas, J.C., Vaqué, C., Duarte, C.M. Agustí, S., 2007. Large-scale variability in surface bacterial carbon demand and 
growth efficiency in the subtropical northeast Atlantic Ocean. Limnology and Oceanography 52, 533-546.

Al-Mutairi, H., Landry, M.R., 2001. Active export of carbon and nitrogen at Station ALOHA by diel migrant zooplankton. Deep-Sea Research II 48, 2083-2103.

Álvarez-Salgado, X.A., Arístegui, J., Barton, E.D., Hansell, D.A., 2007. Contribution of upwelling filaments to offshore carbon export in the subtropical Northeast Atlantic Ocean. Limnology and Oceanography 52, 1287-1292.

Anderson, T.R., Williams, P.J.leB., 1998. Modelling the seasonal cycle of dissolved organic matter at Station $\mathrm{E}_{1}$ in the English Channel. Estuarine, Coastal and Shelf Science 46, 93-109.

Anderson, T.R., Ryabchenko, V.A., Fasham, M.J.R., Gorchakov, V.A., 2007. Denitrification in the Arabian SeaL A 3D ecosystem modelling study. Dee-Sea Research I 54, 2082-2119.

Anderson, T.R., Ryabchenko, V.A., in press. Carbon cycling in the mesopelagic zone of the central Arabian Sea: results from a simple model. In: Wiggert, J. et al. (Eds.), Indian Ocean: Biogeochemical Processes and Ecological Variability. AGU Book Series.

Anderson, T.R., Tang, K.W., 2010. Carbon cycling and POC turnover in the mesopelagic zone of the ocean: insights from a simple model. Deep-Sea Research II 57 (16), 1581-1592.

Andersson, J.H., Wijsman, J.W.M., Herman, P.M.J., Middelburg, J.J., Soetaert, K., Heip, C., 2004. Respiration patterns in the deep ocean. Geophysical Research Letters 31, L03304, doi:10.1029/2003GL018756.

Antia, A.N., 2005. Particle-associated dissolved elemental fluxes, revising the stoichiometry of mixed layer export. Biogeosciences Discussions 2, 275-302.

Antia, A.N., Koeve, W., Fischer, G., Blanz, T., Schulz-Bull, D., Scholten, J., Neuer, S., Kremling, K., Kuss, J., Peinert, R., Hebbeln, D., Bathmann, U., Conte, M., Fehner, U., Zeitzschel, B., 2001. Basin-wide particulate carbon flux in the Atlantic Ocean: regional export patterns and potential for atmospheric $\mathrm{CO}_{2}$ sequestration. Global Biogeochemical Cycles 15, 845-862.

Arístegui, J., Duarte, C.M., Agustí, S., Doval, M., Álvarez-Salgado, X.A., Hansell, D.A., 2002. Dissolved organic carbon support of respiration in the dark ocean. Science 298, 1967.

Arístegui, J., Agustí, S., Duarte, C.Please check doi: no for Arístegui et al., 2003., 2003. Respiration in the dark ocean. Geophysical Research Letters 30, 1041, doi:10.1029/2002GL016227.

Arístegui, J., Agustí, S., Middelburg, J.J., Duarte, C.M., 2005a. Respiration in the mesopelagic and bathypelagic zones of the oceans. In: del Giorgio, P.A., le, P.J., Williams, B. (Eds.), Respiration in Aquatic Systems. Oxford University Press, pp. 181-205.

Arístegui, J., Duarte, C.M., Gasol, J.M., Alonso-Sáez, L., 2005b. Active mesopelagic prokaryotes support high respiration in the subtropical northeast Atlantic Ocean. Geophysical Research Letters 32, L03608, doi:10.1029/2004GL021863.

Arístegui, J., Gasol, J.M., Duarte, C.M., Herndl, G.J., 2009. Microbial oceanography of the dark ocean's pelagic realm. Limnology and Oceanography 54, 1501-1529.

Bailey, T.G., Torres, J.J., Youngbluth, M.J., Owen, G.P., 1994. Effect of decompression on mesopelagic gelatinous zooplankton: a comparison of in situ and shipboard measurements of metabolism. Marine Ecology Progress Series 113, 13-27.

Baltar, F., Arístegui, J., Gasol, J.M., Sintes, E., Herndl, G.J., 2009a. Evidence of prokaryotic metabolism on suspended particulate organic matter in the dark waters of the subtropical North Atlantic. Limnology and Oceanography 54, 182-193.

Baltar, F., Arístegui, J., Sintes, E., van Aken, H.M., Gasol, J.M., Herndl, G.J., 2009b. Prokaryotic extracellular enzymatic activity in relation to biomass production and respiration in the meso- and bathypelagic waters of the (sub)tropical Atlantic. Environmental Microbiology (in press).

Bange, H.W., Rixen, T., Johansen, A.M., Siefert, R.L., Ramesh, R., Ittekkot, V., Hoffmann, M.R., Andreae, M.O., 2000. A revised nitrogen budget for the Arabian Sea. Global Biogeochemical Cycles 14, 1283-1297.

Banse, K., 1990. New views on the degradation and disposition of organic particles as collected by sediment traps in the open sea. Deep-Sea Research 37, 1177-1195.

Boyd, P.W., Newton, P.P., 1999. Does planktonic community structure determine downward particulate organic carbon flux in different oceanic provinces? Deep-Sea Research I 46 63-91.

Boyd, P.W., Sherry, N.D., Berges, J.A., Bishop, J.K.B., Calvert, S.E., Charette, M.A. Giovannoni, S.J., Goldblatt, R., Harrison, P.J., Moran, S.B., Roy, S., Soon, M., Strom, S., Thibault, D., Vergin, K.L., Whitney, F.A., Wong, C.S., 1999. Transformations of biogenic particles from the pelagic to the deep ocean realm. Deep-Sea Research II 46, 2761-2792.

Boyd, P.W., Trull, T.W., 2007. Understanding the export of biogenic particles in oceanic waters: Is there consensus? Progress in Oceanography 72 276-312.

Broecker, W.S., Klas, M., Clark, E., Bonani, G., Ivy, S., Wolffi, W., 1991. The influence of $\mathrm{CaCO}_{2}$ dissolution on core top radiocarbon ages for the deep-sea sediments. Paleoceanography 6, 593-608.

Buesseler, K.O., 1991. Do upper-ocean sediment traps provide an accurate record of particle flux? Nature 353 420-423.

Buesseler, K.O., Steinberg, D.K., Michaels, A.F., Johnson, R.J., Andrews, J.E., Valdes, J.R., Price, J.F., 2000. A comparison of the quantity and composition of material caught in a neutrally buoyant versus surface-tethered sediment trap. Deep-Sea Research I, 277-294.

Buesseler, K.O., Antia, A.N., Chen, M., Fowler, S.W., Gardner, W.D., Gustafsson, O., Harada, K., Michaels, A.F., Rutgers van der Loeff, M., Sarin, M., Steinberg, D.K., Trull, T., 2007. An assessment of the use of sediment traps for estimating upper ocean particle fluxes. Journal of Marine Research 65, 345-416.
Buesseler, K.O., Boyd, P.W., 2009. Shedding light on processes that control particle export and flux attenuation in the twilight zone of the open ocean. Limnology and Oceanography 54, 1210-1232.

Buesseler, K.O., Pike, S., Maiti, K., Lamborg, C.H., Siegel, D.A., Trull, T.W., 2009 Thorium-234 as a local and regional tracer of spatial, temporal and vertical variability in particle flux in the North Pacific. DSRI (in press).

Burd, A.B., Jackson, G.A., 2009. Particle aggregation. Annual Reviews of Marine Science 1, 65-90.

Butman, C.A., 1986. Sediment trap biases in turbulent flows: results from a laboratory flume study. Journal of Marine Research 44, 645-693.

Carlson, C.A., Ducklow, H.W., 1995. Dissolved organic carbon in the upper ocean of the central Equatorial Pacific, 1992: daily and fine0scale vertical variations. Deep-Sea Research II 42, 639-656.

Carlson, C.A., Bates, N.R., Ducklow, H.W., Hansell, D.A., 1999. Estimation of bacterial respiration and growth efficiency in the Ross Sea, Antarctica. Aquatic Microbial Ecology 19, 229-244.

Carlson, C.A., Giovannoni, S.J., Hansell, D.A., Goldberg, S.J., Parsons, R., Otero, M.P. Vergin, K., Wheeler, B.R., 2002. Effect of nutrient amendments in bacterioplankton production, community structure, and DOC utilization in the northwestern Sargasso Sea. Aquatic Microbial Ecology 30, 19-36.

Carlson, C.A., Giovannoni, S.J., Hansell, D.A., Goldberg, S.J., Parsons, R., Vergin, K., 2004. Interactions among dissolved organic carbon, microbial processes, and community structure in the mesopelagic zone of the northwestern Sargasso Sea. Limnology and Oceanography 49, 1073-1083.

Carlson, C.A., Del Giorgio, P.A., Herndl, G.J., 2007. Microbes and the dissipation of energy and respiration: from cells to ecosystems. Oceanography 20, 89-100.

Carlson, C.A., Hansell, D.A., Nelson, N.B., Siegel, D.A., Smethie, W.M., Khatiwala, S., Meyers, M.M., Halewood, E., 2010. Dissolved organic carbon export and subsequent remineralization in the mesopelagic and bathypelagic realms of the North Atlantic basin. Deep-Sea Research II 57 (16), 1433-1445.

Chen, C.-T.A., Liu, K.-K., Macdonald, R., 2003. Continental margin exchanges. In: Fasham., M.J.R. (Ed.), Ocean Biogeochemistry: the Role of the Ocean Carbon Cycle in Global Change. Springer, New York, USA.

Childress, J.J., 1995. Are there physiological and biochemical adaptations of metabolism in deep-sea animals? Trends in Ecology and Evolution 10 (1) 30-36.

Childress, J.J., Thuesen, E.V., 1992. Metabolic potential of deep-sea animals: regional and global scales. In: Rowe, G.T., Parients, V. (Eds.), Deep-Sea Food Chains and the Global Carbon Cycle. Kluwer Academic Press, Norwell, MA, pp. 217-236.

Cho, B.C., Azam, F., 1988. Major role of bacteria in biogeochemical fluxes in the ocean's interior. Nature 332, 441-443.

Christensen, J.P., Owens, T.G., Devol, A.H., Packard, T.T., 1980. Respiration and physiological state in marine bacteria. Marine Biology 55, 267-276.

Clegg, S.L., Whitfield, M., 1990. A generalized model for the scavenging of trace metals in the open ocean-I. Particle cycling. Deep-Sea Research 37, 809-832.

Cochran, J.K., Miquel, J.C., Armstrong, R., Fowler, S.W., Masque, P., Gasser, B. Hirschberg, D., Szlosek, J., Rodriguez y Baena, A., Verdeny, E., Stewart, G., 2009. Time-series measurements of 234Th in water column and sediment trap samples from the northwestern Mediterranean Sea. Deep-Sea Research II 56 1487-1501.

Conte, M.H., Weber, J.C., Ralph, N., 1998. Episodic particle flux in the deep Sargasso Sea: an organic geochemical assessment. Deep-Sea Research I 45, 1819-1841.

Conte, M.H., Ralph, N., Rose, E.H., 2001. Seasonal and interannual variability in deep ocean particle fluxes at the Oceanic Flux Program (OFP)/Bermuda Atlantic Time Series (BATS) site in the western Sargasso Sea near Bermuda. Deep-Sea Research II 48, 1471-1505.

Dehairs, F., Baeyens, W., Goeyens, L., 1992. Accumulation of suspended barite at mesopelagic depths and export production in the Southern Ocean. Science 258, 1132-1135.

Dehairs, F., Shopova, D., Ober, S., Veth, C., Goeyens, L., 1997. Particulate barium stocks and oxygen consumption in the Southern Ocean mesopelagic wate column during spring and early summer: relationship with export production. Deep-Sea Research II 44, 497-516.

Dehairs, F., Jacquet, S., Savoye, N., Va Mooy, B.A.S., Buesseler, K.O., Bishop, J.K.B., Lamborg, C.H., Elskens, M., Baeyens, W., Boyd, P.W., Casciotti, K.L., Monnin, C., 2008. Barium in twilight zone suspended matter as a potential proxy for particulate organic carbon remineralization: results for the North Pacific. Deep-Sea Research II 55, 1673-1683.

del Giorgio, P.A., Cole, J.J., 1998. Bacterial growth efficiency in natural aquatic systems. Annual Review of Ecology and Systematics 29, 503-541.

del Giorgio, P.A., Cole, J.J., 2000. Bacterial energetics and growth efficiency. In: Kirchman, D.L. (Ed.), Microbial Ecology of the Oceans 1st edition Wiley-Liss.

del Giorgio, P.A., Duarte, C.M., 2002. Respiration in the open ocean. Nature 420 379-384

Denman, K.L., Platt, T., 1976. Variance spectrum of phytoplankton in a turbulent ocean. Journal of Marine Research 34, 593-601.

Dixon, J.L., Turley, C.M., 2000. The effect of water depth on bacterial numbers, thymidine incorporation rates and C:N ratios in northeast Atlantic surficial sediments. Hydrobiologia 440, 217-225.

Doval, M.D., Hansell, D.A., 2000. Organic carbon and apparent oxygen utilization in the western South Pacific and the central Indian Oceans. Marine Chemistry 68 249-264.

Ducklow, H.W., 1993. Bacterioplankton distributions and production in the northwestern Indian Ocean and Gulf of Oman, September 1986 
Deep-Sea Research I, 40, 753-771. (Corrigendum: Deep-Sea Research I 47 (2000), 971.

Ducklow, H.W., 2000. Bacterial production and biomass in the oceans. In: Kirchman, D.L. (Ed.), Microbial Ecology of the Oceans. 1st edition Wiley-Liss.

Ducklow, H.W., McCallister, S.L., 2004. The biogeochemistry of carbon dioxide in the Coastal Oceans. In: Robinson, A.R., Brink., K., Rothschild, B.J. (Eds.), The Sea, Vol 13 - The Global Coastal Ocean: Multiscale Interdisciplinary Processes. Harvard University Press.

Fiadeiro, M.E., Craig, H., 1978. 3-Dimensional modeling of tracers in the deep Pacific Ocean. I. Salinity and oxygen. Journal of Marine Research 36, 323-355.

Feely, R.A., Sabine, C.L., Schlitzer, R., Bullister, J.L., Mecking, S., Greeley, D., 2004 Oxygen utilization and organic carbon remineralization in the upper wate column of the Pacific Ocean. Journal of Oceanography 60, 45-52.

Garçon, V.C., Oschlies, A., Doney, S.C., McGillicuddy, D., Waniek, J., 2001. The role of mesoscale variability on plankton dynamics in the North Atlantic. Deep-Sea Research II 48, 2199-2226.

Gardner, W.D., 2000. Sediment trap technology and surface sampling in surface waters. In: Hanson, R.B., Ducklow, H.W., Field, J.G. (Eds.), The Changing Ocean Carbon Cycle, a Midterm Synthesis of the Joint Global Ocean Flux Study. Cambridge University Press.

Gowing, M.M., Garrison, D.L., Wishner, K.F., Gelfman, C., 2003. Mesopelagic microplankton of the Arabian Sea. Deep-Sea Research I 50, 1205-1234.

Guidi, L., Jackson, G.A., Stemmann, L., Miquel, J.C., Picheral, M., Gorsky, G., 2007. Vertical distribution of aggregates $(>110 \mu \mathrm{m})$ and mesoscale activity in the northeastern Atlantic: effects on the deep vertical export of surface carbon. Limnology and Oceanography 52, 7-18.

Hansell, D.A., 2002. DOC in the global ocean cycle. In: Hansell, D.A., Carlson., C.A. (Eds.), Biogeochemistry of Marine Dissolved Organic Matter. Academic Press, San Diego, pp. 685-715.

Hansell, D.A., Carlson, C.A., 1998. Deep-ocean gradients in the concentration of dissolved organic carbon. Nature 395, 263-266.

Hansell, D.A., Carlson, C.A., 2001. Biogeochemistry of total carbon and nitrogen in the Sargasso Sea: control by convective overturn. Deep-Sea Research II 48 , 1649-1667.

Hansell, D.A., Ducklow, H.W., 2003. Bacterioplankton distribution and production in the bathypelagic ocean: directly coupled to particle organic carbon export? Limnology and Oceanography 48, 150-156.

Hansell, D.A., Newton, J.A., 1994. Design and evaluation of a 'swimmer'segregating particle interceptor trap. Limnology and Oceanography 39, 1487-1495.

Hansell, D.A., Olson, D.B., Dentener, F., Zamora, L.M., 2007. Assessment of excess nitrate development in the subtropical North Atlantic. Marine Chemistry 106 $562-579$.

Hernández-León, S., Gómez, M., 1996. Factors affecting the respiration/ETS ratio in marine zooplankton. Journal of Plankton Research 18, 239-255.

Honjo, S., Manganini, S.J., Krishfield, R.A., Francois, R., 2008. Particulate organic carbon fluxes to the ocean interior and factors controlling the biological pump: a synthesis of global sediment trap programs since 1983. Progress in Oceanography 76, 217-285.

Howard, M.T., Winguth, A.M.E., Klass, C., Maier-Reimer, E., 2006. Sensitivity of ocean carbon tracer distributions to particulate organic flux parameterizations. Global Biogeochemical Cycles 20, GB3011, doi:10.1029/2005GB002499.

Howell, E.A., Doney, S.C., Fine, R.A., Olson, D.B., 1997. Geochemical estimates of denitrification in the Arabian Sea and the Bay of Bengal during WOCE. Geophysical Research Letters 24, 2549-2552.

Ikeda, T., 1985. Metabolic rates of epipelagic marine zooplankton as a function of body mass and temperature. Marine Biology 85, 1-11.

Ikeda, T., Sano, F., Yamaguchi, A., Matsuishi, T., 2006. Metabolism of mesopelagic and bathypelagic copepods in the western North Pacific Ocean. Marine Ecology Progress Series 322, 199-211.

Ikeda, T., Sano, F., Yamaguchi, A., 2007. Respiration in marine pelagic copepods: a global-bathymetric model. Marine Ecology Progress Series 339, 215-219.

Jackson, G.A., Kiørboe, T., 2004. Zooplankton use of chemodetection to find and eat particles. Marine Ecology Progress Series 269, 153-162.

Jackson, G.A., 2008. Effect of mixed layer depth on phytoplankton removal by coagulation and on the critical depth concept. Deep-Sea Research I 55, $766-776$

Jahnke, R.A., Jackson, G.A., 1987. Role of sea floor organisms in oxygen consumption in the deep North Pacific Ocean. Nature 329, 621-623.

Jahnke, R.A., 1996. The global ocean flux of particulate organic carbon: area distribution and magnitude. Global Biogeochemical Cycles 10, 71-88.

Jenkins, W.J., 1987. $3 \mathrm{H}$ and $3 \mathrm{He}$ in the beta triangle: observations of gyre ventilation and oxygen utilization rates. Journal of Physical Oceanography 17 $763-783$.

Kadko, D., 2009. Rapid oxygen utilization in the ocean twilight zone assessed with the cosmogenic isotope 7Be. . Global Biogeochemical Cycles 23, GB4010, doi:10.1029/2009GB003510.

Karl, D.M., Laws, E.A., Morris, P., Williams, P.J.L., Emerson, S., 2003. Global carbon cycle (communication arising): metabolic balance of the open sea. Nature 426, 32.

Karstensen, J., Stramma, L., Visbeck, M., 2008. Oxygen minimum zones in the eastern tropical Atlantic and Pacific Oceans. Progress in Oceanography 77 331-335.

Kirchman, D.L., Lancelot, C., Fasham, M., Legendre, L., Radach, G., Scott, M., 1993. Dissolved organic matter in biogeochemical models of the ocean. In: Evans,
G.T., Fusham, M.J.R. (Eds.), "Towards a Model of Biogeochemical Ocean Processes".. Springer-Verlag, Berlin Heidelberg.

Kiørboe, T., Jackson, G.A., 2001. Marine snow, organic solute plumes, and optical chemosensory behavior of bacteria. Limnology and Oceanography 46, 1309-1318.

Kiørboe, T., Thygesen, U.H., 2001. Fluid motion and solute distribution around sinking aggregates. II. Implications for remote detection by colonizing zooplankters. Marine Ecology Progress Series 211, 15-25.

Kiørboe, T., Tang, K., Grossart, H.-P., Ploug, H., 2003. Dynamics of microbial communities on marine snow aggregates: colonization, growth, detachment, and grazing mortality of attached bacteria. Applied and Environmental Microbiology 69, 3036-3047.

Kobari, T., Shinada, A., Tsuda, A., 2003. Functional roles of interzonal migrating mesozooplankton in the western subarctic Pacific. Progress in Oceanography 57, 279-298.

Kobari, T., Steinberg, D.K., Ueda, A., Tsuda, A., Silver, M.A., Kitamura, M., 2008. Impacts of ontogenetically migrating copepods on downward carbon flux in the western subarctic Pacific Ocean. Deep-Sea Research II 55, $1648-1660$.

Koppelmann, R., Weikert, H., 1999. Temporal changes of deep-sea mesozooplankton abundance in temperate NE Atlantic and estimates of the carbon budget. Marine Ecology Progress Series 179, 27-40.

Koppelmann, R., Weikert, H., 2007. Spatial and temporal distribution patterns of deep-sea mesozooplankton in the eastern Mediterranean - indications of a climatically induced shift? Marine Ecology 28 259-275.

Koppelmann, R., Frost, J., 2008. The ecological role of zooplankton in the twilight and dark zones of the ocean. In: Mertens, L.P. (Ed.), Biological Oceanography Research Trends.. Nova Science Publishers, Inc., New York, pp. 67-130.

Koppelmann, R.H., Schäfer, P., Schiebel, R., 2000. Organic carbon losses measured by heterotrophic activity of mesozooplankton and $\mathrm{CaCO}_{3}$ flux in the bathypelagic zone of the Arabian Sea. Deep-Sea Research II 47, 169-187.

Koppelmann, R., Weikert, H., Halsband-Lenk, C., 2004. Mesozooplankton community respiration and its relation to particle flux in the oligotrophic eastern Mediterranean. Global Biogeochemical Cycles 18, GB1039, doi:10.1029/ 2003 GB002121.

Koppelmann, R., Böttger-Schnack, R., Möbius, J., Weikert, H., 2009. Trophic relationships of zooplankton in the eastern Mediterranean based on stable isotope measurements. Journal of Plankton Research 31, 669-686.

Lamborg, C.H., Buesseler, K.O., Valdes, J., Bertrand, C.H., Bidigare, R., Manganini, S., Pike, S., Steinberg, D.K., Trull, T., Wilson, S., 2008. The flux of bio- and lithogenic material associated with sinking particles in the mesopelagic "twilight zone" of the northwest and North Central Pacific Ocean. Deep-Sea Research II 55, 1540-1563.

Lampitt, R.S., Antia, A.N., 1997. Particle flux in deep seas: Regional characteristics and temporal variability. Deep-Sea Research I 44, 1377-1403.

Lampitt, R.S., Bett, B.J., Kiriakoulakis, K., Popova, E.E., Ragueneau, O., Vangriesheim, A., Wolf, G.A., 2001. Material supply to the abyssal seafloor in the Northeast Atlantic. Progress in Oceanography 50, 27-63.

La Ferla, R., Azzaro, M., 2001. Microbial respiration in the Levantine Sea: evolution of the oxidative processes in relation to the main Mediterranean water masses. Dee-Sea Research I 48, 2147-2159.

Laws, E.A., Falkowski, P.G., Smith Jr., W.O., Ducklow, H., McCarthy, J.J., 2000. Temperature effects on export production in the open ocean. Global Biogeochemical Cycles 14, 1231-1246.

Lefèvre, D., Denis, M., Lambert, C.E., Miquel, J.-C., 1996. Is DOC the main source of organic matter remineralization in the ocean water column. Journal of Marine Science 7, 281-291.

Lévy, M., Gavart, M., Mémery, L., Caniaux G., Paci, A., 2005. A 4D-mesoscale map of the spring bloom in the northeast Atlantic (POMME experiment): results of a prognostic model. J. Geophys. Res. 110 C07S21 10.1029/2004JC002588.

Liu, K.-K., Iseki, K., Chao, S.-Y., 2000a. Continental margin carbon fluxes. In: Hanson, R.B., Ducklow, H.W., Field, J.G. (Eds.), The Changing Ocean Carbon Cycle: a Midterm Synthesis of the Joint Global Ocean Flux Study. Cambridge University Press, Cambridge, England.

Liu, K.-K., Atkinson, L., Chen, C.T.A., Gao, S., Hall, J., MacDonald, R.W., Talaue McManus, L., Quiñones, R., 2000b. Exploring continental margin carbon fluxes on a global scale. EOS 81, 641-644.

Longhurst, A.R., Bedo, A.W., Harrison, W.G., Head, EJ.H., Sameoto, D.D. 1990. Vertical flux of respiratory carbon by oceanic diel migrant biota. Deep-Sea Research 37, 685-694.

López-Urrutia, A, Morán, X.A.G., 2007. Resource limitation of bacterial production distorts the temperature dependence of oceanic carbon cycling. Ecology 88, 817-822.

Lutz, M., Dunbar, R., Caldeira, K., 2002. Regional variability in the vertical flux of particulate organic carbon in the ocean interior. Global Biogeochemical Cycles 16, 1037, doi:10.1029/2000GB001383.

Madin, L.P., Kremer, P., Purcell, J.E., Nemazie, D.A., 1994. Vertical migration of a large Salpa aspera population in the North Atlantic slope water. EOS 75, 90.

Martin, J.H., Knauer, G.A., Karl, D.M., Broenkow, W.W., 1987. VERTEX: carbon cycling in the northeast Pacific. Deep-Sea Research 34, 267-286.

Martin, J.H., Fitzwater, S.E., Gordon, R.M., Hunter, C.N., Tanner, S.J., 1993. Iron, primary production and carbon-nitrogen flux studies during the JGOFS North Atlantic Bloom Experiment. Deep-Sea Research II 40, 115-134.

Michaels, A.F., Bates, N.R., Buesseler, K.O., Carlson, C.A., Knap, A.H., 1994. Carboncycle imbalances in the Sargasso Sea. Nature 372, 537-540.

Munk, W., 1966. Abyssal recipes. Deep-Sea Research I 13, 707-730. 
Murray, J., 1895. General observations on the distribution of marine organisms. Report of the Scientific Results of the Voyage of H.M.S. Challenger Summary of Scientific Results 2, 1431-1462.

Nagata, T., Fukuda, H., Fukuda, R., Koike, I., 2000. Bacterioplankton distribution and production in deep Pacific waters: large-scale geographic variations and possible coupling with sinking particle fluxes. Limnology and Oceanography $45,426-435$.

Nagata, T., Tamburini, C., Arístegui, J., Baltar, F., Bochdansky, A.B., Fonda-Umani, S., Fukuda, H., Gogou, A., Hansell, D.A., Hansman, R.L., Herndl, G.J, Panagiotopoulos, C., Reinthaler, T., Sohrin, R., Verdugo, P., Yamada, N., Yamashita, Y., Yokokawa, T., Bartlett, D.H., 2010. Emerging concepts on microbial processes in the bathypelagic ocean - ecology, biogeochemistry and genomics. Deep-Sea Research II 57 (16), 1519-1536.

Naqvi, S.W.A., Shailaja, M.S., 1993. Activity of the respiratory electron transport system and respiration rates within the oxygen minimum layer of the Arabian Sea. Deep-Sea Research II 40, 687-695.

Naqvi, S.W.A., Kumar, M.D., Narvekar, P.V., De Sousa, S.N., George, M.D., D’Silva, C., 1993. An intermediate nepheloid layer associated with high microbial metabolic rates and denitrification in the northwest Indian Ocean. Journal of Geophysical Research 98, 16469-16479.

Newton, P.P., Lampitt, R.S., Jickells, T.D., King, P., Boutle, C., 1994. Temporal and spatial variability of biogenic particle fluxes during the JGOFS northeast Atlantic process studies at $47^{\circ} \mathrm{N}, 20^{\circ} \mathrm{W}$. Deep-Sea Research I 41, 1617-1642.

Packard, T.T., 1971. The measurement of electron respiratory transport activity in marine phytoplankton. Journal of Marine Science 29, 235-244.

Packard, T.T., Denis, M., Rodier, M., Garfield, P., 1988. Deep ocean metabolic $\mathrm{CO}_{2}$ production-calculations from ETS activity. Deep-Sea Research I 35, 371-382.

Paffenhöfer, G.-A., 2006. Oxygen consumption in relation to motion of marine planktonic copepods. Marine Ecology Progress Series 317, 187-192.

Phillips, B., Kremer, P., Madin, L.P., 2009. Defecation by Salpa thompsoni and its contribution to vertical flux in the Southern Ocean. Marine Biology 156, 455-467.

Ploug, H., Grossart, H.-P., 1999. Bacterial production and respiration in suspended aggregates - a matter of the incubation method. Aquatic Microbial Ecology 20, 21-29.

Primeau, F., 2006. On the variability of the exponent in the power law depth dependence of POC flux estimated from sediment traps. Deep-Sea Research I 53, 1335-1343.

Reinthaler, T., van Aken, H., Veth, C., Aristegui, J., Robinson, C., Williams, P.J., le, B., Lebaron, P., Herndl, G.J., 2006. Prokaryotic respiration and production in the meso- and bathypelagic realm of the eastern and western North Atlantic basin. Limnology and Oceanography 51, 1262-1273.

Reinthaler, T., van Aken, H.M., Herndl, G.J., 2010. Major contribution of autotrophy to microbial carbon cycling in the deep North Atlantic's interior. Deep-Sea Research II 57 (16), 1572-1580.

Rivkin, R.B., Legendre, L., 2001. Biogenic carbon cycling in the upper ocean: effects of microbial respiration. Science 291, 2398-2400.

Robinson, C., 2008. Heterotrophic bacterial respiration. In: Kirchman, D.L. (Ed.), Microbial Ecology of the Oceans. 2nd edition John Wiley \& Sons.

Robinson, C., Steinberg, D.K., Koppelmann, R., Robison, B., Anderson, T.R., Arístegui J., Carlson, C.A., Frost, J.R., Ghiglione, J.-F., Hernández-León, S., Jackson, G., Queguiner, B., Ragueneau, O., Rassoulzadegan, F., Tamburini, C., Tanaka, T., Wishner, K.F., Zhang, J., 2010. Mesopelagic zone ecology and biogeochemistrya synthesis. Deep-Sea Research II 57 (16), 1504-1518.

Robison, B.H., 2004. Deep pelagic biology. Journal of Experimental Marine Biology and Ecology 300, 253-272.

Robison, B.H., Bailey, T.G., 1981. Sinking rates and dissolution of midwater fish fecal matter. Marine Biology 65, 135-142.

Robison, B.H., Reisenbichler, K.R., Sherlock, R.E., 2005. Giant larvacean houses: rapid carbon transport to the deep sea floor. Science 308, 1609-1611.

Robison, B.H., Sherlock, R.E., Reisenbichler, K.R., 2010. The bathypelagic community of the Monterey Canyon. Deep-Sea Research II 57 (16), 1551-1556.

Schlitzer, R., 2004. Export production in the Equatorial and North Pacific derived from dissolved oxygen, nutrient and carbon data. Journal of Oceanography 60, 53-62.

Scholten, J.C., Fietzke, J., Vogler, S., Rutgers van der Loeff, M.M., Mangini, A., Koeve, W., Waniek, J., Stoffers, P., Antia, A., Kuss, J., 2001. Trapping efficiencies of sediment traps from the deep Eastern North Atlantic: the ${ }^{230}$ Th calibration. Deep-Sea Research II 48, 2382-2408.

Schmitz, W.J., 1996a. On the World Ocean Circulation: Volume 1. Some Global Features/North Atlantic Circulation. Woods Hole Oceanographic Institution. Technical Report WHOI-96-03. 141pp.

Schmitz, W.J., 1996b. On the World Ocean Circulation. The Pacific and Indian Oceans - A Global Update. Volume II. Woods Hole Oceanographic Institution. Technical Report WHOI-96-08, 241pp.

Sherry, N.D., Imanian, B., Sugimoto, K., Boyd, P.W., Harrison, P.J., 2002. Seasonal and interannual trends in heterotrophic bacterial processes between 1995 and 1999 in the subarctic NE Pacific. Deep-Sea Research II 49, 5775-5791.

Shopova, D., Dehairs, F., Baeyens, W., 1995. A simple model of biogeochemical element distribution in the oceanic water column. Journal of Marine Systems $6,331-344$.

Siegel, D.A., Deuser, W.G., 1997. Trajectories of sinking particles in the Sargasso Sea: modeling of statistical funnels above deep-ocean sediment traps. DeepSea Research I 44, 1519-1541.
Siegel, D.A., Court, D.B., Menzies, D.W., Peterson, P., Maritorena, S., Nelson, N.B. 2008. Satellite and in situ observations of the bio-optical signatures of two mesoscale eddies in the Sargasso Sea. Deep-Sea Research II 55, 1218-1236.

Simon, M., Welschmeyer, N.A., Kirchman, D.L., 1992. Bacterial production and the sinking flux of particulate organic matter in the subarctic Pacific. Deep-Sea Research A 39, 1997-2008.

Smith, D.C., Simon, M., Alldredge, A.L., Azam, F., 1992. Intense hydrolytic enzyme activity on marine aggregates and implications for rapid particle dissolution. Nature 359, 139-142.

Smith Jr, K.L., 1982. Zooplankton of a bathyal benthic boundary layer: In situ rates of oxygen consumption and ammonium excretion. Limnology and Oceanography $27,461-471$.

Smith Jr, K.L., 1985. Macrozooplankton of a deep sea hydrothermal vent: In situ rates of oxygen consumption. Limnology and Oceanography 30, 102-110.

Smith Jr, K.L., Carlucci, A.F., Williams, P.M., Henrichs, S.M., Baldwin, R.J., Graven, D.B., 1986. Zooplankton and bacterioplankton of an abyssal benthic boundary layer: in situ rates of metabolism. Oceanologica Acta 9, 47-55.

Smith, K.L., Kaufmann, R.S., 1999. Long-term discrepancy between food supply and demand in the deep Eastern North Pacific. Science 284, 1174-1177.

Smith, S.V., Hollibaugh, J.T., 1993. Coastal metabolism and the oceanic organic carbon balance. Reviews of Geophysics 31, 75-89.

Sohrin, R., Imazawa, M., Fukuda, H., Suzuki, Y., 2010. Full-depth profiles of bacteria, heterotrophic nanoflagellates, and ciliates along a transect from the equatorial to the subarctic central Pacific Ocean. Deep-Sea Research II 57 (16), 1537-1550.

Somayajulu, B.L.K., Sarin, M.M., Ramesh, R., 1996. Denitrification in the eastern Arabian Sea: Evaluation of the role of continental margins using Ra isotopes. Deep-Sea Research I 43, 111-117.

Somero, G.N., Siebenaller, J.F., Hochachka, P.W., 1983. Biochemical and physiological adaptations of deep-sea animals. In: Rowe, G.T. (Ed.), The Sea, Volume 8, Deep Sea Biology. John Wiley and Sons, New York, USA.

Steinberg, D.K., Van Mooy, B.A.S., Buesseler, K.P., Boyd, P.W., Kobari, T., Karl, D.M., 2008. Bacterial vs. zooplankton control of sinking particle flux in the ocean's twilight zone. Limnology and Oceanography 53, 1327-1338.

Steinberg, D.K., Carlson, C.A., Bates, N.R., Goldthwait, S.A., Madin, L.P. Michaels, A.F., 2000. Zooplankton vertical migration and the active transport of dissolved organic and inorganic carbon in the Sargasso Sea. Deep-Sea Research I 47, 137-158.

Steinberg, D.K., Silver, M.W., Pilskaln, C.H., 1997. The role of mesopelagic zooplankton in the community metabolism of giant larvacean house detritus in Monterey Bay, California, USA. Marine Ecology Progress Series 147, 167-179.

Tanaka, T., Rassoulzadegan, F., 2002. Full-depth profile $(0-2000 \mathrm{~m})$ of bacteria, heterotrophic nanoflagellates and ciliates in the NW Mediterranean Sea: vertical partitioning of microbial trophic structures. Deep-Sea Research II 49, 2093-2107.

Tamburini, C., Garcin, J., Ragot, M., Bianchi, A., 2002. Biopolymer hydrolysis and bacterial production under ambient hydrostatic pressure through a $2000 \mathrm{~m}$ water column in the NW Mediterranean. Deep-Sea Research II 49 (11) 2109-2123.

Tamburini, C., Garcin, J., Bianchi, A., 2003. Role of deep-sea bacteria in organic matter mineralization and adaptation to hydrostatic pressure conditions in the NW Mediterranean Sea. Aquatic Microbial Ecology 32, 209-218.

Tamburini, C., Garcin, J., Grégori, G., Leblanc, K., Rimmelin, P., Kirchman, D.L., 2006 Pressure effects on surface Mediterranean prokaryotes and biogenic silica dissolution during a diatom sinking experiment. Aquatic Microbial Ecology 43 267-276.

Tamburini, C., Garel, M., Al Ali, B., Mérigot, B., Kriwy, P., Charrière, B. Budillon, G., 2009a. Distribution and activity of Bacteria and Archaea in the different water masses of the Tyrrhenian Sea. Deep-Sea Research II 56 (11-12), 700-712.

Tamburini, C., Goutx, M., Guige, C., Garel, M., Lefèvre, D., Charrière, B., Sempéré, R., Pepa, S., Peterson, M.L., Wakeham, S., Lee, C., 2009b. Effect of hydrostatic pressure on microbial alteration of sinking fecal pellets. Deep-Sea Research II $56,1533-1546$

Thuesen, E.V., Childress, J.J., 1994. Oxygen consumption rates and metabolic enzyme activities of oceanic California medusae in relation to body size and habitat depth. Biol. Bull. 187, 84-98.

Thuesen, E.V., Miller, C.B., Childress, J.J., 1998. Ecophysiological interpretation of oxygen consumption rates and enzymatic activities of deep-sea copepods. Marine Ecology Progress Series 168, 95-107.

Trull, T.W., Bray, S.G., Buesseler, K.O., Lamborg, C.H., Manganini, S., Moy, C. Valdes, J., 2008. In situ measurement of mesopelagic particle sinking rates and control of carbon transfer to the ocean interior during the Vertical Flux in the Global Ocean (VERTIGO) voyages in the North Pacific. Deep-Sea Research II 55 , 1684-1695.

Turley, C.M., Lochte, K., Lampitt, R.S., 1995. Transformations of biogenic particles during sedimentation in the northeastern Atlantic. Phil. Trans. R. Soc. Lond. B 348, 179-189.

Verdugo, P., Santschi, P.H., 2010. Polymer physics of DOM networks and ge formation in seawater. Deep-Sea Research II 57 (16), 1486-1493.

Vinogradov, G.M., 2005. Vertical distribution of macroplankton at the CharlieGibbs Fracture Zone (North Atlantic), as observed from the manned submersible "Mir- 1". Marine Biology 146, 325-331.

Wiebe, P.H., Madin, L.P., Haury, L.R., Harbison, G.R., Philbin, L.M., 1979. Die vertical migration by Salpa aspera and its potential for large-scale 
particulate organic matter transport to the deep sea. Marine Biology 53, 249-255.

Wishner, K.F., Gowing, M.M., Gelfman, C., 2000. Living in suboxia: ecology of an Arabian Sea oxygen minimum zone copepod. Limnology and Oceanography 45, 1576-1593.

Yamaguchi, A., Watanabe, Y., Ishida, H., Harimoto, T., Furusawa, K., Suzuki, S., Ishizaka, J., Ikeda, T., Takahashi, M.M., 2002. Structure and size distribution of plankton communities down to greater depths in the western North Pacific Ocean. Deep-Sea Research II 49, 5513-5529.

Yu, E.-F., Francois, R., Bacon, M.P., Honjo, S., Fleer, A.P., Manganini, S.J., Rutgers van der Loeff, M.M., Ittekkot, V., 2001. Trapping efficiency of bottom-tethered sediment traps estimated from the intercepted fluxes of ${ }^{230} \mathrm{Th}$ and ${ }^{230} \mathrm{~Pa}$. DeepSea Research I 48, 865-889. 